\title{
CONSERVAÇÃO DE GOIABAS 'PEDRO SATO' TRATADAS COM 1-METILCICLOPROPENO: CONCENTRAÇÕES E TEMPOS DE EXPOSIÇÃO
}

\section{ELIANE BASSETTO}

Dissertação apresentada à Escola Superior de Agricultura "Luiz de Queiroz", Universidade de São Paulo, para obtenção do ítulo de Mestre em Agronomia, Área de Concentração: Fitotecnia.

PIRACICABA

Estado de São Paulo - Brasil

Novembro - 2002 


\section{CONSERVAÇÃO DE GOIABAS 'PEDRO SATO' TRATADAS COM 1-METILCICLOPROPENO: CONCENTRAÇÕES E TEMPOS DE EXPOSIÇÃO}

\section{ELIANE BASSETTO}

Engenheiro Agrônomo

Orientador: Prof. Dr. ANGELO PEDRO JACOMINO

Dissertação apresentada à Escola Superior de Agricultura "Luiz de Queiroz", Universidade de São Paulo, para obtenção do título de Mestre em Agronomia, Área de Concentração: Fitotecnia.

PIRACICABA

Estado de São Paulo - Brasil

Novembro - 2002 


\section{Dados Internacionais de Catalogação na Publicação (CIP)} DIVISÃO DE BIBLIOTECA E DOCUMENTAÇÃO - ESALQ/USP

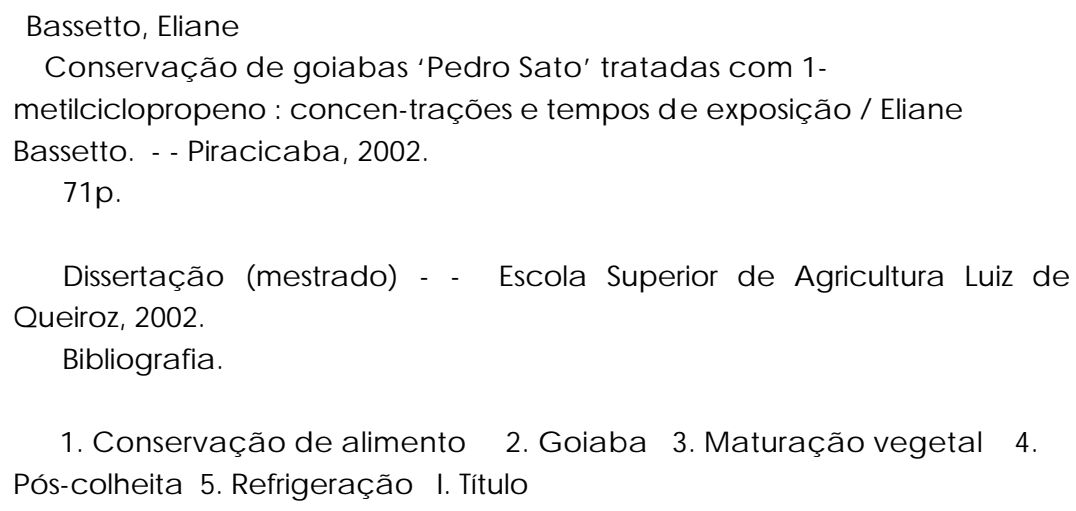

CDD 634.421

"Permitida a cópia total ou parcial deste documento, desde que citada a fonte - O autor" 
Ao meu querido pai Orivaldo,

e àminha mãe Eini (in memorian),

pelo constante incentivo, amor, e carinho.

Às minhas irmãs Telma, Fábia, Angélica e Juliana;
e à Evaldete que partilham comigo desta vitória.

Aos meus lindos sobrinhos: Vinícius, Marcelinho, Natália, Letícia e Giovana pela constante alegria.

Aos meus avós João e Guilina,

que com simplicidade e sabedoria ensinaram-me

as lições do trabalho e da honestidade 


\section{AGRADECIMENTOS}

À Deus, por estar sempre presente em minha vida, possibilitando mais uma vitória.

A Comissão do Curso de Pós-Graduação em Fitotecnia pela oportunidade de realização do curso de mestrado.

A Capes pela concessão da bolsa, possibilitando a realização de meu estudo.

Ao Prof. Dr. Angelo Pedro Jacomino pela orientação, paciência, amizade e dedicação demonstrada em cada etapa deste trabalho.

Ao Prof. Dr. Ricardo Alfredo Kluge pela amizade, revisão dos trabalhos e pela grande contribuição para minha formação profissional.

Ao Prof. Dr. Rogério Lopes Vieites pela excelente base que adquiri com seus ensinamentos na área de pós-colheita de frutas e hortaliças.

Aos Profs. Dr. Paulo Roberto de Camargo e Castro e Dr. Roberval De Cássia Ribeiro pela oportunidade de ser monitora.

Ao Prof. Dr. Murilo de Melo pelo incentivo, amizade e revisão dos summaries.

A todos os professores do Departamento de Produção Vegetal pela agradável convivência.

Aos produtores de goiaba, Srs. Waldenir Rossi e Ricardo Rossi pela doação dos frutos para a realização dos experimentos e pela confiança. 
À Walter Pereira da empresa Rohm \& Haas pela amizade, e pelo fornecimento das amostras de 1-MCP.

Aos funcionários do Depto de Produção Vegetal, em especial, Aparecido, Barbosa, Bete, Célia, Davi, Éder, Helena, Ivete, Judite, Odair e Tiago pelos mais diversos tipos de ajuda.

A Luciane Lopes que serei eternamente grata por todo seu esforço, incentivo e amizade.

Aos integrantes do grupo de pós-colheita pela colaboração nas análises físico-químicas.

A Ana Luíza pela pronta ajuda em todos os trabalhos necessários.

Aos amigos Adriana, Amanda, Amaral, Aureny, Carlos, Carol, Cecília, Curtiça, Dani, Flávia, Fuji, Gambé, Gláucio, Graça, Hector, Helena, Ilana, Magali, Maria do Carmo, Marisa, Phynna, Potira, Rosana, Sérgio, Sutil, Silvana Bueno e Sílvio pela força e companheirismo.

Especialmente à amiga Smurf, pela incansável ajuda nos momentos mais difíceis, pelos conselhos e pela grande amizade.

Aos colegas do curso de Pós-Graduação em Fitotecnia pela agradável convivência. 


\section{SUMÁRIO}

\section{Página}

RESUMO.

viii

SUMMARY

$\mathrm{X}$

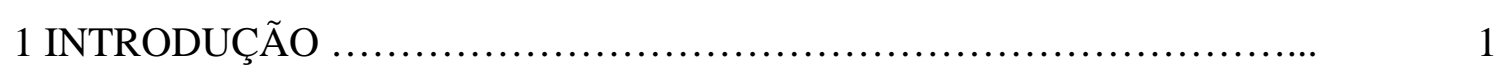

2 REVISÃO DE LITERATURA ............................................ 3

2.1 Aspectos gerais sobre a cultura da goiabeira.................................................... 3

2.2 Fisiologia pós-colheita da goiaba .....................................................................

2.2.1 Maturação e amadurecimento dos frutos ..........................................................

2.2.2 Padrão de atividade respiratória ……………………………………........

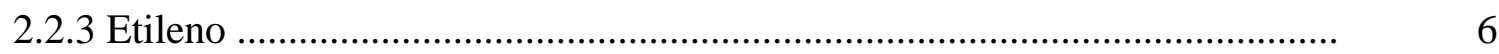

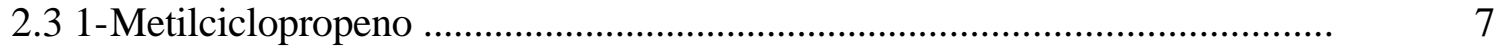

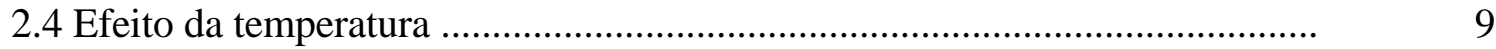

3 AVALIAÇÃO DE CONCENTRAÇÕES DE 1-METILCICLOPROPENO (1MCP) E TEMPOS DE EXPOSIÇÃO NA CONSERVAÇÃO 11 REFRIGERADA DE GOIABAS 'PEDRO SATO'

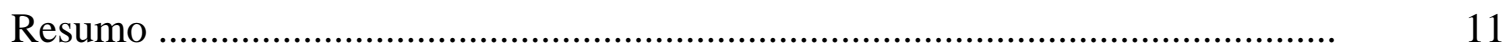

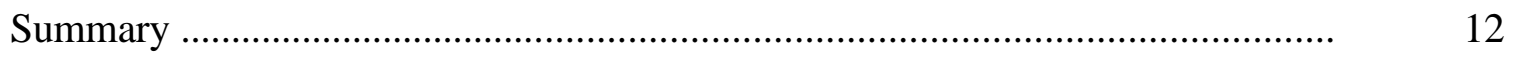

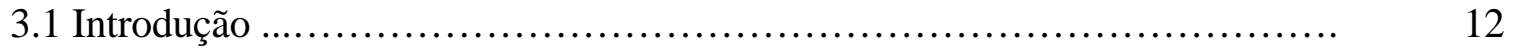

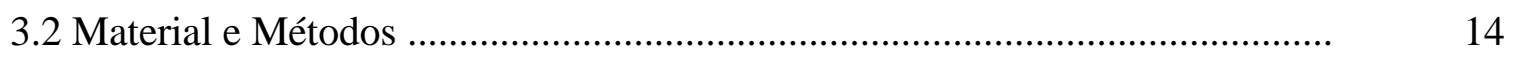

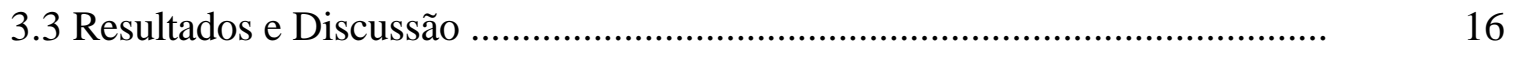

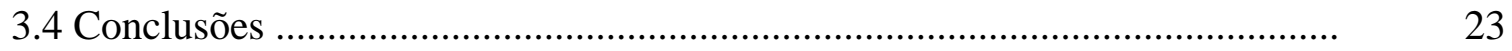


4 CONCENTRAÇÕES DE 1-METILCICLOPROPENO (1-MCP) E TEMPOS DE EXPOSIÇÃO NA CONSERVAÇÃO DE GOIABAS 'PEDRO SATO' EM CONDIÇÃO AMBIENTE

Resumo

Summary 25

4.1 Introdução 25

4.2 Material e Métodos 27

4.3 Resultados e Discussão 29

4.4 Conclusões 38

5 CONSERVAÇÃO DE GOIABAS 'PEDRO SATO' TRATADAS COM 1MCP DURANTE 3 HORAS E ARMAZENADAS SOB CONDIÇÃO AMBIENTE E SOB REFRIGERAÇÃO

Resumo 39

Summary 40

5.1 Introdução 41

5.2 Material e Métodos 42

5.3 Resultados e Discussão 44

5.4 Conclusões 57

6 CONCLUSÕES GERAIS ..... 58

REFERÊNCIAS BIBLIOGRÁFICAS 60 


\title{
CONSERVAÇÃO DE GOIABAS 'PEDRO SATO' TRATADAS COM 1-METILCICLOPROPENO: CONCENTRAÇÕES E TEMPOS DE EXPOSIÇÃO
}

\author{
Autora: ELIANE BASSETTO \\ Orientador: Prof. Dr. ANGELO PEDRO JACOMINO
}

\section{RESUMO}

O objetivo deste trabalho foi verificar os efeitos de concentrações de 1metilciclopropeno (1-MCP) em tempos de exposição na conservação de goiabas 'Pedro Sato' armazenadas sob condição ambiente e sob refrigeração. No primeiro experimento as goiabas foram tratadas com 0, 60, 120 e $240 \mathrm{~nL} . \mathrm{L}^{-1}$ de 1-metilciclopropeno durante 3, 6 e 12 horas e armazenadas a $10^{\circ} \mathrm{C}$ durante 14 e 21 dias $\left(+2\right.$ dias a $\left.25^{\circ} \mathrm{C}\right)$. No segundo experimento as goiabas foram tratadas com $0,100,300$ e 900 nL.L $L^{-1}$ de 1 metilciclopropeno durante 3,6 e 12 horas e armazenadas a $25^{\circ} \mathrm{C}$. No terceiro experimento as goiabas foram tratadas com 0, 100, 300 e 900 nL.L - $^{-1}$ de 1metilciclopropeno durante 3 horas e armazenadas a $25^{\circ} \mathrm{C}$ e a $10^{\circ} \mathrm{C}$. No primeiro experimento as características físico-químicas foram avaliadas aos 14 e aos 21 dias após os tratamentos. No segundo experimento as características foram avaliadas quando os frutos atingiram o completo amadurecimento. No terceiro experimento as características físico-químicas foram avaliadas aos 2, 4, 6 e 8 dias de armazenamento para os frutos armazenados a $25^{\circ} \mathrm{C}$ e aos $4,8,12$ e 16 dias de armazenamento para os frutos armazenados a $10^{\circ} \mathrm{C}$. Os frutos tratados com $240 \mathrm{~nL} . \mathrm{L}^{-1}$ de 1-MCP durante 6 e $12 \mathrm{~h} \mathrm{e}$ armazenados durante 14 dias a $10^{\circ} \mathrm{C}$ apresentaram melhor retenção da coloração da 
casca e menor incidência de podridão, porém quando colocados por 2 dias a $25^{\circ} \mathrm{C}$ apesar de apresentarem melhor firmeza e menor incidência de podridões, não mantiveram a cor verde da casca. O 1-MCP não fi eficiente em retardar o amadurecimento dos frutos tratados nas concentrações de 60,120 e $240 \mathrm{~nL} . \mathrm{L}^{-1}$ e $\operatorname{armazenados}$ a $10^{\circ} \mathrm{C}$. A concentração de $300 \mathrm{~nL} \cdot \mathrm{L}^{-1}$ de $1-\mathrm{MCP}$ durante 6 e $12 \mathrm{~h}$ e a concentração de $900 \mathrm{~nL} . \mathrm{L}^{-1}$ durante 3 horas, permitiram a conservação dos frutos por 9 dias sob condição ambiente. A aplicação de 1-MCP nas concentrações de 100, 300 e 900 nL. $L^{-1}$ retardou o amadurecimento dos frutos armazenados tanto no ambiente como sob refrigeração. $\mathrm{O}$ tratamento com $900 \mathrm{~nL} \cdot \mathrm{L}^{-1}$ de 1 -MCP durante 3 horas foi considerado o mais eficiente em retardar o amadurecimento dos frutos nas duas temperaturas de armazenamento. Este tratamento permitiu a conservação dos frutos por 16 dias em ambiente refrigerado. 


\section{CONSERVATION OF 'PEDRO SATO' GUAVAS TREATED WITH 1-METHYLCYCLOPROPENE: CONCENTRATIONS AND EXPOSURE TIME}

Author: ELIANE BASSETTO

Adviser: Prof. Dr. ANGELO PEDRO JACOMINO

\section{SUMMARY}

The objective of this study was to study the effect of 1methylcyclopropene (1-MCP) concentration and exposure time treatments on the postharvest conservation of 'Pedro Sato' guava fruits at room temperature and at refrigerated storage conditions. Three different experiments were carried out. In the first, guava fruits were treated with $0,60,120$ or $240 \mathrm{~nL} \cdot \mathrm{L}^{-1}$ of 1 -methylcyclopropene for 3,6 or 12 hours and stored at $10^{\circ} \mathrm{C}$ for 14 and 21 days (plus 2 days at $25^{\circ} \mathrm{C}$ ). In the second, the guava fruits, were treated with $0,100,300$ or 900 nL.L ${ }^{-1}$ of 1 -methylcyclopropene for 3,6 or 12 hours and stored at $25^{\circ} \mathrm{C}$. In third, the guava fruits were treated with 0 , 100,300 or $900 \mathrm{~nL} \cdot \mathrm{L}^{-1}$ of 1-methylcyclopropene for 3 hours and stored at $25^{\circ} \mathrm{C}$ and at $10^{\circ} \mathrm{C}$. The physicalchemical characteristics of the fruits were evaluated at 14 and 21 days, when the guavas fruits were completely ripen, and at the days 2, 4, 6 and 8 of storage for fruits stored under room temperature and at days 4, 8, 12 and 16 of storage for fruits storage under refrigerated conditions for the first, second and third experiment, respectively. Fruits treated with 240 nL.L $\mathrm{L}^{-1}$ of 1 -MCP for 6 and 12 hours stored for 14 days at $10^{\circ} \mathrm{C}$ showed better retention of skin color and smaller decay incidence, although the fruits stored for 2 days at $25^{\circ} \mathrm{C}$ showed better firmness and smaller 
decay incidence, all of the fruits not maintain green skin color. The 1-MCP concentrations of 60,120 or $240 \mathrm{~nL} . \mathrm{L}^{-1}$ and $10^{\circ} \mathrm{C}$ storage conditions were not efficient on delaying treated fruit ripening. The concentration of $300 \mathrm{~nL} . \mathrm{L}^{-1}$ of $1-\mathrm{MCP}$ for 6 and $12 \mathrm{~h}$, and the concentration of $900 \mathrm{~nL} \cdot \mathrm{L}^{-1}$ for 3 hours, allowed the better conservation of the fruits for 9 days at room temperature. 1-MCP was efficient on delaying fruits ripening under room temperature storage conditions. The 1-MCP 100, 300 or 900 nL.L ${ }^{-1}$ concentrations treatments delayed the ripening of fruits stored under room temperature and under refrigerated conditions. The $900 \mathrm{~nL} . \mathrm{L}^{-1}$ of $1-\mathrm{MCP}$ for 3 hours treatment was considered to be the most efficient on delaying fruits ripening in the both storage temperatures conditions. Also this treatment allowed conservation of the fruits for 16 days under refrigeration. 


\section{INTRODUÇÃO}

A goiaba é originária da América Tropical, e difundiu-se para todas as regiões tropicais e subtropicais do mundo. É uma planta da família das Mirtáceas, do gênero Psidium, sendo Psidium guajava L. a espécie mais conhecida no Brasil (Manica et al., 2000). Sua produção em escala industrial no País teve início na década de 70 , quando

grandes áreas tecnificadas foram implantadas, com produção direcionada para o mercado nacional e internacional, na forma in natura, industrializada (doces e sucos) e desidratada (Choudhury et al., 2001).

Comparada a outras frutas tropicais, a goiaba destaca-se por apresentar elevado valor nutritivo, pois é ótima fonte de vitamina $\mathrm{C}$ e possui considerável teor de vitamina A, tiamina, niacina, fósforo e ferro (Castro \& Sigrist, 1988).

Atualmente, o Brasil é o maior produtor mundial de goiabas e os pomares se acham concentrados nos estados de São Paulo e Pernambuco, onde respondem por mais de $80 \%$ da produção nacional (Agrianual, 2000). A produção brasileira é de aproximadamente 260.000 toneladas anuais (Agrianual, 2001). A comercialização da fruta para mesa ocorre o ano todo (Zambão \& Bellintani Neto, 1998), havendo maior oferta no período de janeiro a março. São comercializadas anualmente na Ceagesp aproximadamente 10.000 toneladas desta fruta (Agrianual 2001). A participação no mercado internacional da goiaba in natura é inexpressiva. Em 2000, o Brasil exportou somente $0,06 \%$ de sua produção, estando entre os maiores compradores a França, o Canadá, o Reino Unido e os Países Baixos (Choudhury, et al., 2001). Alguns fatores são responsáveis por esse problema, entre os quais destaca-se o pouco conhecimento do produto por parte dos consumidores e o alto grau de perecibilidade do fruto na fase póscolheita. Este último fator exige que o produto seja bem acondicionado e escoado para o mercado internacional via aérea, o que onera demasiadamente os custos de 
comercialização. Sendo assim, o mercado de goiaba continua acentuadamente dependente do mercado nacional.

O armazenamento e comercialização de produtos vegetais sob refrigeração é uma das possibilidades de manter a qualidade do fruto. $\mathrm{O}$ abaixamento da temperatura resulta em redução da atividade respiratória de frutos e, conseqüientemente, aumento no período de conservação (Hardenburg et al., 1986).

O 1-metilciclopropeno (1-MCP) tem demonstrado ser um potente antagonista da ligação do etileno ao seu sítio na célula, atuando tanto sobre o etileno endógeno quanto exógeno. Tem sido utilizado com sucesso na conservação de flores, hortaliças e frutos. Recentemente, foi verificado um aumento na vida útil destes produtos de forma bastante efetiva, mantendo uma boa qualidade.

O tempo de exposição ao 1-MCP, recomendado para a maioria dos produtos hortícolas, é de 12 horas para que se obtenha boa eficiência do produto. Porém caso de goiaba, este tempo de exposição é muito longo, o que pode dificultar o uso do 1-MCP. Em vista disso, o presente trabalho teve por objetivo determinar se concentrações maiores de 1-MCP em tempos menores de exposição são eficazes na conservação de goiabas 'Pedro Sato', com e sem refrigeração. 


\section{REVISÃO DE LITERATURA}

\subsection{Aspectos gerais sobre a cultura da goiabeira}

$\mathrm{O}$ mercado atual valoriza e remunera melhor os frutos das variedades do grupo de polpa avermelhada e de casca rugosa, que possui a preferência da maioria dos consumidores (Zambão \& Bellintani Neto, 1998).

As plantas da cultivar Pedro Sato são vigorosas e bastante produtivas, produzindo frutos grandes de formato oblongo com a polpa firme, espessa, de cor rosada, sabor agradável, com uma cavidade central cheia e com poucas sementes, sendo

a casca bem rugosa. É uma das cultivares mais difundidas dentre as goiabas de polpa vermelha no Estado de São Paulo (Pereira, 1995; Manica et al., 2000).

A época normal de produção da goiaba encontra-se entre janeiro e março, mas através de práticas culturais como a poda e irrigação, é possível realizar a colheita durante o ano todo (Manica et al., 2000).

As goiabas são frutos altamente perecíveis e possuem uma atividade metabólica intensa. Quando mantida à temperatura ambiente, atingem o amadurecimento completo entre 3 e 5 dias (Gongatti Netto et al., 1996). A qualidade da goiaba para o consumo ao natural está relacionada com seus atributos físicos, como aparência, tamanho, forma, cor e firmeza, bem como à sua composição química, responsável pelo sabor e aroma (Gongatti Netto et al., 1996). Essas características variam principalmente de acordo com o cultivar, o estádio de maturação, as condições climáticas do local de cultivo e as condições de colheita e manuseio pós-colheita, tendo conseqüências diretas sobre a conservação e qualidade dos frutos (Carvalho, 1994). Frutos colhidos na estação chuvosa têm qualidade inferior por causa do maior teor de umidade e diluição dos constituintes químicos (Rathore, 1976). Quando os frutos são colhidos "de vez", a 
senescência também é rápida, ocorrendo entre 2 e 4 dias após o amadurecimento completo do fruto. Por essas razões, o ponto de colheita ideal é considerado um fator importante para a manutenção da qualidade e está na dependência do destino que será dado ao fruto durante a comercialização (Choudhury, 2001). Para o mercado in natura os frutos devem ser colhidos com textura firme e coloração da casca passando da cor verde escuro para verde claro, havendo um início de formação da cor amarela na base dos frutos (Carvalho, 1994).

\subsection{Fisiologia pós-colheita da goiaba}

As técnicas de conservação visam reduzir tanto a taxa respiratória quanto à síntese e ação do etileno, mantendo-se os frutos na fase pré-climatérica por período mais longo (Salunkhe \& Desai, 1984; Kays, 1991). A maturidade fisiológica do fruto na colheita e os fatores ambientais como temperatura, umidade e composição da atmosfera de armazenamento influenciam a duração do período pré-climatérico (Bleinroth et al., 1992). O rápido amaciamento da polpa favorece a incidência de podridões causadas por infecções fúngicas, sendo mais comum a antracnose, causada pelo fungo Colletotrichum gloeosporioides (Jeffries et al., 1990).

Diversos tratamentos pós-colheita têm sido testados na goiaba, como o uso de absorvedores de etileno (Ahlawat et al., 1980), aplicações de cálcio (Xisto, 2002; Sing et al., 1981), ceras (Ojeda, 2001; Combrink et al., 1990), reguladores de crescimento (Saha, 1971), fungicidas (Ojeda, 2001; Castro \& Sigrist, 1991), termoterapia (Yusof \& Hashim, 1992), atmosfera modificada (Jacomino, 1999; Gaspar, 1997), dentre outros. Embora muitos destes tratamentos sejam eficientes em retardar a maturação, reduzir a deterioração e conservar a qualidade dos frutos, alguns interferem na aparência, no sabor e aroma e estendem a vida-de-prateleria de forma economicamente inexpressiva ou deixam resíduos químicos.

\subsubsection{Maturação e amadurecimento dos frutos}

$\mathrm{Na}$ fase final do desenvolvimento do fruto, quando este atinge o seu tamanho máximo, ocorre a maturação, que envolve significativas alterações bioquímicas e 
fisiológicas (Chitarra \& Chitarra, 1990). A etapa final da maturação corresponde ao amadurecimento e envolve uma série de mudanças que resultam na alteração da estrutura e composição dos frutos tornando-os aceitáveis para o consumo (Wills et al., 1981). O amadurecimento marca a transição dos estádios de crescimento para a senescência (Rhodes, 1970; Bruisma, 1981).

Em frutos climatéricos, como na maioria das cultivares de goiaba, o amadurecimento é um processo complexo que requer grande quantidade de energia (Bruisma, 1981), estando associado com um rápido aumento da taxa respiratória dos frutos colhidos e da taxa de síntese de etileno (Beaudry et al., 1993; Inaba, 1993)

\subsubsection{Padrão de atividade respiratória}

A respiração é um dos principais fatores determinantes do potencial de longevidade das frutas na fase de pós-colheita, estando intimamente ligada à temperatura e à concentração de gases ao redor das mesmas (Kader, 1986; Chitarra \& Chitarra, 1990).

Embora, alguns trabalhos citem a goiaba como sendo uma fruta com padrão de atividade respiratória do tipo não climatérico (Biale \& Barcus, 1970; Yamashita \& Benassi, 1998; e Chitarra \& Chitarra, 1990), inúmeros trabalhos tem demonstrado o contrário. Srivastava \& Narasimhan (1967); Carvalho (1994); Durigan (1997); Gaspar et al.(1997) ; McGuire (1997) e Gonzaga Neto et al. (1999) citaram em seus trabalhos que a goiaba é um fruto climatérico por apresentar aumentos acentuados na taxa respiratória e na liberação de etileno durante a fase de maturação. Akamine \& Goo (1979) analisaram a respiração de duas cultivares de $P$. guajava e duas de $P$. cattleianum, no estádio de plena maturação e verificaram que todas apresentaram respiração climatérica e pico de produção de etileno bem definidos. Lima et al. (1998) estudando o comportamento respiratório da variedade Pedro Sato colhidos em dois estádios de maturação ("verde" e "de vez"), chegaram a conclusão de que as mesmas são climatéricas. Da mesma forma, Brown \& Wills (1983) estudaram o comportamento de 6 cultivares de $P$. guajava colhidas em quatro diferentes estádios de maturação, desde 
frutos imaturos a totalmente desenvolvidos e verificaram comportamento respiratório e de produção de etileno do tipo climatérico.

\subsubsection{Etileno}

$\mathrm{O}$ etileno $\left(\mathrm{C}_{2} \mathrm{H}_{4}\right)$ é um fitohormônio que está envolvido na aceleração do amadurecimento e senescência de frutos climatéricos. Este fitohormônio, encontrado nos espaços intercelulares, tem como precursor primário o aminoácido metionina, como intermediário o SAM (S-adenosilmetionina) e como precursor imediato o ACC (ácido aminociclopropano carboxílico). A enzima ACC sintase catalisa a reação de formação do ACC a partir do SAM, e a enzima ACC oxidase oxida o ACC formando o etileno (Kluge et al., 2002).

O mecanismo de ação do etileno consiste na sua ligação a uma molécula receptora, provavelmente uma proteína (ETR1), que possui um sítio de ligação do fitohormônio. A ativação do mesmo segue através de dois passos possíveis: o próprio receptor ativa o fitohormônio ou, o que parece mais provável, uma via de sinalização formada por mensageiros secundários vão ao núcleo da célula e induzem a expressão gênica (transcrição). Consequientemente há formação de novos RNAs e novas proteínas, desencadeando uma série de respostas inerentes ao etileno (Kluge et al., 2002), como o amadurecimento e senescência do fruto ( Burg \& Burg, 1967; Lelièvre et al., 1997).

Partindo deste princípio, a inibição da ligação do etileno ao seu receptor pode reduzir a produção autocatalítica e a ação do mesmo e, com isso, retardar o amadurecimento e a senescência de frutos climatéricos.

Vários compostos são capazes de bloquear a ligação do $\mathrm{C}_{2} \mathrm{H}_{4}$ ao seu receptor na célula, causando a inibição dos efeitos deste hormônio. Foi verificado que compostos como o 2,5 norbornadiene (NBD) e o diazocyclopentadiene (DACP), ambos inibidores da ligação do etileno na célula, podem retardar o amolecimento e amadurecimento de maçãs (Blankenship \& Sisler, 1989 e 1993; Gong \& Jian, 1998). O tiosulfato de prata foi muito usado comercialmente em flores de corte e flores envasadas devido inibir a ação do etileno (Serek \& Reid, 1993). Entretanto, nenhum destes compostos é comercialmente aceito devido à sua toxidez e impactos ambientais. 


\subsection{1-Metilciclopropeno}

O 1-metilciclopropeno (1-MCP) é um composto volátil recentemente descoberto e que tem demonstrado ser um eficiente inibidor da ação do etileno (Serek et al., 1995). Age através de fixação preferencial ao receptor de etileno, bloqueando deste modo, os efeitos do etileno procedentes de fontes internas e externas. Provavelmente, essa preferência ao receptor é devido ao baixo $\mathrm{km}$ do 1-MCP, $17 \mathrm{~nL} . \mathrm{L}^{-1}$, em comparação com 96nL.L $\mathrm{L}^{-1}$ do etileno, demonstrando sua maior afinidade aos receptores do etileno (Jiang et al, 1999a). O 1-MCP se liga ao receptor de etileno de maneira irreversível, o posterior amadurecimento do fruto é devido à formação de novos receptores de etileno (Feng et al., 2000; Jiang et al., 1999b; Sisler et al., 1996).

Embora o 1-MCP seja um gás, ele tem sido formulado como pó, com o nome comercial de $\operatorname{SmartFresh}^{\circledR}$, o qual libera o 1-MCP quando misturado a uma solução básica ou água.

O 1-MCP retarda a senescência de flores cortadas e plantas envasadas quando aplicado em baixíssimas concentrações (Serek et al., 1994 e 1995; Porat et al., 1995; Sisler et al., 1996). Recentes estudos indicaram que o 1-MCP pode suprimir a produção de etileno e com isso, retardar o amadurecimento de muitos frutos como goiaba (Kluge et al., 2000), maçã (Rupasinghe et al., 2000; Watkins et al., 2000; Fan et al., 1999), banana (Harris et al., 2000; Sisler \& Serek, 1997; Golding et al., 1998; e Jiang et al., 1999a), ameixa (Abdi et al., 1998), damasco (Fan et al., 2000), abacate (Feng et al., 2000), tomate (Nakatsuka et al., 1997; Sisler \& Serek, 1997), brocoli (Fan et al., 2000; Ku \& Wills, 1999) e morango (Ku \& Wills, 1999).

A concentração de 1-MCP necessária para apresentar efeito no bloqueio da ação do etileno varia conforme a espécie, cultivar, estádio de maturação, temperatura de exposição (Rupasingue et al., 2000), interação concentração x tempo de exposição e produção de novos receptores de etileno (Watkins et al., 2000).

Sisler \& Serek (1997), verificaram o efeito do 1-MCP em baixíssima concentração, $0,5 \mathrm{~nL} . \mathrm{L}^{-1}$, em flores de cravo e banana, expostos durante $24 \mathrm{~h}$ ao produto a temperatura de $24^{\circ} \mathrm{C}$. Entretanto, para o tomate foi necessária a aplicação de $7 \mathrm{~nL} \cdot \mathrm{L}^{-1}$ de 1-MCP para conseguir o mesmo efeito. 
Harris et al. (2000), aplicaram 0, 5, 50 e 500nL.L $\mathrm{L}^{-1}$ de $1-\mathrm{MCP}$ em bananas 'Williams' em 3 estádios de maturação durante $24 \mathrm{~h}$ a $20^{\circ} \mathrm{C}$ e depois armazenaram os frutos em câmaras a $20^{\circ} \mathrm{C}$ contendo $0,1 \mu \mathrm{L} \cdot \mathrm{L}^{-1}$ de etileno. Esses autores verificaram que apenas a concentração de $500 \mathrm{~nL} \cdot \mathrm{L}^{-1}$ retardou o amadurecimento dos frutos nos 3 estádios de maturação e o efeito do 1-MCP foi maior nos frutos mais maduros do que nos frutos mais verdes.

Fan et al. (2000), verificaram o efeito do 1-MCP em damascos em diferentes estádios de maturação, e concluíram que o $1-\mathrm{MCP}$ foi eficaz em retardar o amadurecimento em todos os estágios, porém quanto maior o grau de maturação menor foi o efeito do 1-MCP sobre a firmeza dos frutos.

A concentração a ser utilizada do 1-MCP, depende da temperatura de tratamento. Em baixas temperaturas deve-se utilizar maior concentração do produto, provavelmente devido à afinidade do $1-\mathrm{MCP}$ ao receptor de etileno ser menor do que em altas temperaturas (Sisler et al.,1996). Maçãs 'Cortland' tratadas com $0,6 \mu L L^{-1}$ de 1MCP a $3^{\circ} \mathrm{C}$ apresentaram melhor firmeza quando expostos no mínimo por $9 \mathrm{~h}$ ao produto, enquanto que os frutos tratados a $13^{\circ}$ e a $23^{\circ} \mathrm{C}$ precisaram de apenas $6 \mathrm{~h}$ para apresentar o mesmo efeito. Entretanto, maçãs 'Empire' tratadas com a mesma concentração e independente das temperaturas $\left(3^{\circ}, 13^{\circ}\right.$ ou $\left.23^{\circ} \mathrm{C}\right)$, apresentaram melhor firmeza com apenas 3h de exposição ao 1-MCP (DeEll et al., 2002).

Existe interação entre concentração e tempo de exposição ao 1-MCP. Quanto maior o tempo de exposição ao produto menor será a concentração para se obter o efeito desejado. Jiang et al. (1999a), observaram que em bananas tratadas com 100nL.L $\mathrm{L}^{-1}$ de 1MCP durante $12 \mathrm{~h}$ apresentaram o mesmo efeito que aquelas tratadas com $1000 \mathrm{~nL} . \mathrm{L}^{-1}$ de 1-MCP durante $3 \mathrm{~h}$.

Em abacate foi verificado que os frutos tratados com $0,45 \mu L \cdot L^{-1}$ de $1-\mathrm{MCP}$ durante 24h apresentaram maior conservação do que os frutos tratados com a mesma concentração durante os tempos de exposição de 6 e $12 \mathrm{~h}$, e que os frutos tratados com $0,09 \mu \mathrm{L} \cdot \mathrm{L}^{-1}$ de 1-MCP independente do tempo de exposição não apresentaram diferença quanto aos frutos não tratados (Jeong et al.,2002). 
Em tomates, o 1-MCP preveniu o acúmulo de mRNAs que codificam a expressão da ACC sintase, ACC oxidase e do receptor de etileno envolvido na regulação autocatalítica de produção de etileno (Sistema 2) (Nakatsuka et al., 1997). Harris et al. (2000), verificaram que bananas 'Williams' tratadas com 500nL.L ${ }^{-1}$ de 1-MCP durante $24 \mathrm{~h} \mathrm{a} 20^{\circ} \mathrm{C}$, apresentaram maior retenção do amadurecimento do que bananas não tratadas, quando expostas a $0,1 \mu \mathrm{L} . \mathrm{L}^{-1}$ de etileno. Provavelmente o acúmulo de mRNAs necessários para a transição do sistema 1 para o sistema 2 de produção de etileno foram bloqueados ou retardados pelo 1-MCP.

\subsection{Efeito da temperatura}

A temperatura é o fator individual do armazenamento mais importante na manutenção da qualidade dos frutos, porque as taxas de muitos processos metabólicos são dependentes da temperatura dentro de uma faixa de temperatura fisiológica (Inaba, 1993).

As reações enzimáticas envolvidas na respiração são governadas pela temperatura. Para cada $10^{\circ} \mathrm{C}$ de aumento na temperatura, a taxa respiratória aproximadamente dobra ou triplica. A mudança na taxa segue a Lei de Vant Hoff, a qual exprime que a taxa das reações químicas e bioquímicas aumenta de 2 a 3 vezes com o aumento de $10^{\circ} \mathrm{C}$ na temperatura. Quanto mais rápido um produto respira, maior a quantidade de calor gerado. Portanto, a diminuição da temperatura no armazenamento é de vital importância para retardar a respiração (Hardenburg et al., 1986).

A temperatura durante o armazenamento influencia a síntese de etileno (Burg, 1962) e torna mais lenta a sua ação (Inaba, 1993). Desta forma, retarda o amadurecimento dos frutos além de reduzir a taxa de crescimento de microrganismos (Reyes e Paull, 1995). Conseqüentemente, há um aumento no período de conservação (Hardenburg et al., 1986).

A temperatura de armazenamento pode atenuar ou agravar certas desordens fisiológicas (Gran \& Beaudry, 1993). Baixa temperatura de armazenamento é benéfica porque as taxas de respiração e metabolismo são reduzidas. Entretanto, baixa temperatura não suprime todos os processos metabólicos na mesma extensão. Algumas 
reações são sensíveis à baixa temperatura e cessam completamente abaixo de uma temperatura crítica. Desta forma, pode ocorrer um desequilíbrio no metabolismo, levando ao colapso das células e manifestação de distúrbios fisiológicos (Wills et al., 1981).

As frutas tropicais, como a goiaba, são muito sensíveis ao frio e podem apresentar uma série de características indesejáveis, como alterações na taxa de respiração e de produção de etileno, escurecimento da casca e/ou da polpa, incapacidade para o amadurecimento normal, menor resistência ao ataque de microorganismos e perda do aroma e do sabor (Pantástico, 1975).

Yahia (1998) e Chitarra \& Chitarra (1990), recomendam o armazenamento entre 5 a $10^{\circ} \mathrm{C}$ até no máximo 3 semanas. Gaspar et al. (1997) observaram danos por “chilling" em goiabas armazenadas a $7^{\circ} \mathrm{C}$, durante 3 semanas. Segundo Durigan (1997), a temperatura mínima varia de acordo com o cultivar e o estádio de maturação. Salunkhe \& Desai (1984) afirmam que frutos colhidos "verdes" ou "de vez" apresentam sintomas de "chilling injury" quando armazenados a temperaturas inferiores a $8^{\circ} \mathrm{C}$. Já os frutos maduros são mais resistentes ao "chilling", mas são mais susceptíveis ao ataque de fungos, principalmente quando estocados a temperatura superiores a $11^{\circ} \mathrm{C}$.

Vasquez-Ochoa \& Colinas-Leon (1990) obtiveram os melhores resultados de conservação de goiabas quando estas foram armazenadas a $7^{\circ} \mathrm{C}$. Frutas armazenadas a $3,5^{\circ} \mathrm{C}$ apresentaram "chilling", enquanto aquelas armazenadas a $11^{\circ} \mathrm{C}$ apresentaram diminuição do tempo de armazenamento, devido ao aumento do ataque pelos fungos.

Segundo Jacomino et al. (2000) goiabas 'Kumagai' armazenadas a $10^{\circ} \mathrm{C}$ ou $12^{\circ} \mathrm{C}$ podem ser conservadas por 14 dias e se armazenadas a $8^{\circ} \mathrm{C}$ podem ser conservadas por 21 dias. 


\section{AVALIAÇÃO DE CONCENTRAÇÕES DE 1-METILCICLOPROPENO (1-MCP) E TEMPOS DE EXPOSIÇÃO NA CONSERVAÇÃO REFRIGERADA DE GOIABAS 'PEDRO SATO'}

\section{Resumo}

Goiabas 'Pedro Sato' foram tratadas com 0, 60, 120 e 240 nL.L ${ }^{-1}$ de 1metilciclopropeno durante 3,6 e 12 horas e armazenadas a $10^{\circ} \mathrm{C}$ durante 14 e 21 dias (+ 2 dias a $25^{\circ} \mathrm{C}$ ). $\mathrm{O}$ delineamento experimental foi inteiramente casualizado com 4 repetições de 6 frutos por tratamento, em cada período de armazenamento. Foram analisadas as seguintes variáveis: coloração da casca, coloração da polpa, perda de massa, firmeza da polpa, acidez total titulável (ATT), teor de ácido ascórbico, teor de sólidos solúveis totais (SST) e incidência de podridões. Os teores de ácidos, sólidos solúveis, vitamina $\mathrm{C}$ e a coloração da polpa, não foram influenciados pelos tratamentos. As goiabas tratadas com $240 \mathrm{~nL} \cdot \mathrm{L}^{-1}$ de $1-\mathrm{MCP}$ apresentaram discreta manutenção da coloração da casca quando comparadas aos demais tratamentos, porém de forma não significativa. Comportamento semelhante foi observado para a firmeza da polpa. A porcentagem de podridão diminuiu com o aumento da concentração de 1-MCP e do tempo de exposição. Apesar da tendência dos resultados, os efeitos do 1-MCP foram muito discretos e não implicaram em ganho efetivo de conservação das goiabas armazenadas a $10^{\circ} \mathrm{C}$, provavelmente, devido as baixas concentrações de 1-MCP utilizadas para o armazenamento refrigerado.

Palavras-chave: Psidium guajava, 1-metilciclopropeno, concentração e tempo de exposição, refrigeração. 


\section{EVALUATION OF CONCENTRATIONS AND EXPOSURE TIMES OF 1-METHYLCYCLOPROPENE (1-MCP) IN THE COLD STORAGE OF 'PEDRO SATO’ GUAVAS}

\section{Summary}

'Pedro Sato' guavas fruit were treated with $0,60,120$ or $240 \mathrm{~nL} . \mathrm{L}^{-1}$ of 1 methylcyclopropene (1-MCP) for 3, 6 or 12 hours and stored at $10^{\circ} \mathrm{C}$ for 14 and 21 days (plus 2 days at $25^{\circ} \mathrm{C}$ ). A completely randomized experimental design was with four replicates of six fruits for each treatment, in both stored period was followed. Skin color, pulp color, weight loss, firmness, total titrable acidity, ascorbic acid, total soluble solids and decay incidence were evaluated. The ascorbic acids, soluble solids, titrable acidity and the pulp color were not affected by the treatments. The treated guava fruits with 240 nL. $\mathrm{L}^{-1}$ of 1-MCP showed discreet retention of the skin color when compared to the other treatments, although in no significant way. Similar behavior was observed for the pulp firmness. The decay incidence was inversely related to the 1-MCP concentrations and exposure times. In spite of results tendency, the effect of the $1-\mathrm{MCP}$ treatment at $10^{\circ} \mathrm{C}$ was very discreet and did not confer to guava fruits conservation performance, probably, reflecting the low concentrations of $1-\mathrm{MCP}$ used for the refrigerated storage conditions.

Key-words: Psidium guajava, 1-methylcyclopropene, concentration, exposure time, refrigeration.

\subsection{Introdução}

A goiaba é uma fruta nativa da América Tropical e atualmente pode ser encontrada em todas as regiões do Brasil (Choudhury, 2001). É uma fruta muito popular no Brasil e constitui uma elevada fonte de vitamina $\mathrm{C}$ para o ser humano. Apresenta excelentes características organolépticas e alto rendimento em polpa, tornando-a 
adequada tanto para o consumo in natura quanto para a industrialização (Carvalho, 1994).

As goiabas são frutos altamente perecíveis e possuem uma atividade metabólica intensa. Quando mantida à temperatura ambiente, atingem o amadurecimento completo entre 3 e 5 dias (Gongatti Netto et al., 1996). Os principais fatores depreciadores da qualidade pós-colheita de goiabas são a rápida perda da coloração verde da casca, amolecimento excessivo, elevada incidência de podridões, murchamento dos frutos e perda de brilho (Jacomino, 1999). Desta forma, o emprego de métodos que possibilitem retardar o amadurecimento são benéficos para ampliar o período de comercialização.

$\mathrm{O}$ armazenamento em temperaturas baixas é um método eficiente para manter a qualidade dos produtos hortícolas, devido aos seus efeitos de redução nos processos de respiração, transpiração, produção de etileno, amadurecimento, senescência e desenvolvimento de podridões (Hardenburg et al., 1986). Invariavelmente, o abaixamento da temperatura aumenta o período de conservação. Em frutos climatéricos, como a maioria das variedades de goiaba, a redução da temperatura retarda o pico climatérico e, por conseqüência, o seu amadurecimento (Kader, 1992).

$\mathrm{O}$ armazenamento em baixa temperatura, em algumas condições pode ser prejudicial, em função de danos fisiológicos que podem causar. Os sintomas de danos pelo chilling em frutas tropicais são: alterações na taxa de respiração e de produção de etileno, escurecimento da casca e polpa, irregularidade no amadurecimento, menor resistência à podridões e perda do aroma e sabor (Pantastico, 1975).

$\mathrm{O}$ etileno $\left(\mathrm{C}_{2} \mathrm{H}_{4}\right)$ está envolvido na aceleração do amadurecimento e senescência de frutos climatéricos. Em um determinado estádio da maturação, o $\mathrm{C}_{2} \mathrm{H}_{4}$ presente nos espaços intercelulares se liga ao seu receptor na célula e desencadeia uma série de eventos que culminam com o amadurecimento e senescência do fruto (Burg \& Burg, 1967; Lelièvre et al., 1997). Partindo deste princípio, a inibição da ligação do etileno ao seu receptor pode reduzir a produção autocatalítica e a ação do mesmo e, com isso, retardar o amadurecimento e a senescência de frutos climatéricos.

O 1-metilciclopropeno (1-MCP) é um composto volátil recentemente descoberto e que tem demonstrado ser um eficiente inibidor da ação do etileno (Serek et al., 1995). 
Embora o 1-MCP seja um gás, ele tem sido formulado como pó, com o nome comercial de SmartFresh ${ }^{\circledR}$, o qual libera o 1-MCP quando misturado a uma solução básica ou água. O 1-MCP se liga ao sítio de ligação do etileno, atuando como antagonista do etileno.

Recentes estudos indicaram que o 1 -MCP pode suprimir a produção de etileno e com isso, retardar o amadurecimento de muitos frutos como goiaba (Kluge et al., 2000), maçã (Rupasinghe et al., 2000; Watkins et al., 2000; Fan et al., 1999), banana (Harris et al., 2000; Sisler \& Serek, 1997; Golding et al., 1998; e Jiang et al., 1999a e 1999b), ameixa (Abdi et al., 1998), damasco (Fan et al., 2000), abacate (Feng et al., 2000), tomate (Nakatsuka et al., 1997; Sisler \& Serek, 1997), brocoli (Fan et al., 2000; Ku \& Wills, 1999) e morango (Ku \& Wills, 1999).

Considerando o crescente mercado de goiabas in natura e a pouca durabilidade desta fruta após a colheita, o presente trabalho teve como objetivo determinar se as concentrações de 60, 120, e 240 nL.L ${ }^{-1}$ de 1 -MCP nos tempos de 3, 6 e 12 horas de exposição têm efeito na conservação de goiabas 'Pedro Sato' armazenadas sob refrigeração.

\subsection{Material e Métodos}

Goiabas 'Pedro Sato' foram colhidas em pomar comercial localizado no município de Vista Alegre do Alto (SP), em março de 2002 e transportadas ao Laboratório de Pós-colheita de Produtos Hortícolas do Departamento de Produção Vegetal da ESALQ/USP, em Piracicaba (SP). Foram utilizados frutos sem defeitos, em estádio de maturação caracterizado pela mudança da cor da casca de verde-escuro para verde-claro, com massa de $164 \pm 20 \mathrm{~g}$.

Os frutos foram pré-resfriados e quando a temperatura da polpa atingiu $10^{\circ} \mathrm{C}$, foram submetidos aos tratamentos com Smartfresh ${ }^{\circledR}$, na formulação pó molhável, contendo $0,14 \%$ de i.a. 1-MCP. Foram utilizadas as seguintes concentrações de 1-MCP:

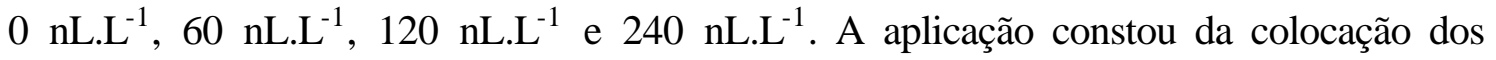
frutos em câmara hermética e exposição ao produto por período de $3 \mathrm{~h}$, 6h e $12 \mathrm{~h}$ a temperatura de $10^{\circ} \mathrm{C}$. Para produzir a concentração desejada de $1 \mathrm{MCP}$ no interior da 
câmara, quantidade pré-determinada de Smartfresh $^{\circledR}$, foi colocada em frasco com tampa $\left(0,16 \mathrm{~g}\right.$ de Smartfresh ${ }^{\circledR}$ representam $100 \mathrm{~nL} \cdot \mathrm{L}^{-1}$ de 1 -MCP em $\left.1 \mathrm{~m}^{3}\right)$. Adicionou-se $20 \mathrm{ml}$ de água destilada a $50^{\circ} \mathrm{C}$ e agitourse o frasco até a completa dissolução do produto. $\mathrm{O}$ frasco foi aberto no interior da câmara, a qual foi fechada imediatamente para evitar a perda do gás. Após os tratamentos, as câmaras foram abertas e os frutos foram armazenados em câmara refrigerada a $10^{\circ} \mathrm{C}$ durante 14 e 21 dias.

$\mathrm{O}$ delineamento experimental adotado foi inteiramente casualizado, em esquema fatorial. Os fatores estudados foram concentração de 1-MCP e tempo de exposição ao produto. Foram utilizadas quatro repetições por tratamento com seis frutos por parcela, totalizando 600 frutos.

As frutas foram analisadas a cada 3 dias quanto à perda de massa e coloração da casca. As demais características foram avaliadas no início do experimento, aos 14 e aos 21 dias após os tratamentos.

As variáveis analisadas foram: a) Coloração da casca e da polpa: determinada através de colorímetro Minolta CR-300, e os resultados expressos em ângulo de cor $\left({ }^{\circ} \mathrm{h}\right)$ para cor da casca e croma (C) para cor da polpa. $\mathrm{O}$ h $^{\circ}$ define a coloração básica, onde $0^{\circ}$ $=$ vermelho, $90^{\circ}=$ amarelo e $180^{\circ}=$ verde $\mathrm{O}$ croma define a saturação e intensidade da cor definida pelo $\mathrm{lf}^{\mathrm{f}}$ (McGuirre, 1992). Para cor da casca, realizaram-se duas leituras em lados opostos da região equatorial e para cor da polpa, uma leitura no centro da região placentária, após corte transversal; b) Perda de massa: por diferença, em \%, entre a massa inicial e final da repetição; c) Firmeza da polpa: determinada com penetrômetro digital, ponteira $8 \mathrm{~mm}$, tomando-se duas leituras por fruta, em lados opostos da região equatorial e os resultados expressos em Newton; d)Acidez total titulável (ATT): determinada por titulometria de acordo com metodologia de Carvalho et al. (1990) e os resultados expressos em \% de ácido átrico; e)Teor de ácido ascórbico: determinado por titulometria de acordo com metodologia descrita por Carvalho et al. (1990), sendo os resultados expressos em mg de ácido ascórbico por 100g de polpa e f)Teor de sólidos solúveis totais (SST): determinada através de leitura direta em refratômetro digital Atago modelo Palete 101, utilizando-se uma amostra centrifugada da fruta, expressando os 
resultados em ${ }^{\circ}$ Brix, g) Incidência de podridões: a incidência foi avaliada pela contagem do número de frutos afetados, sendo os resultados expressos em porcentagem.

Os resultados foram submetidos à analise de variância (teste F) e, em caso de significância, as médias foram comparadas pelo teste de Tukey ao nível de 5\% de probabilidade.

\subsection{Resultados e Discussão}

Os frutos armazenados a $10^{\circ} \mathrm{C}$ apresentaram gradual redução da cor verde da casca ao longo do armazenamento, o que pode ser observado pelo ângulo de cor $\left(\mathrm{h}^{\circ}\right)$. Esta variável representa a variação entre as cores amarela $\left(h^{\circ}=90\right)$ e verde $\left(h^{\circ}=180\right)$. As goiabas foram armazenadas com $h^{\circ}=113$ (verde-claro) e atingiram valores de $h^{\circ}$ entre 107,9 a 98,0, ao final do armazenamento (verde-amarelo).

De um modo geral o efeito do 1-MCP foi bastante discreto na retenção da cor da casca dos frutos armazenados a $10^{\circ} \mathrm{C}$ (Figura 1). Não houve diferença entre os tempos de exposição, independente da concentração estudada, provavelmente devido ao efeito da baixa temperatura de armazenamento sobre o metabolismo dos frutos. Segundo Mir et al. (2001), é possível que a afinidade dos sítios de ligação do etileno pelo 1-MCP, seja diminuída em baixas temperaturas. Observou-se apenas uma ligeira retenção da cor da casca nos frutos tratados com 240nL.L ${ }^{-1}$ de 1-MCP, porém, de forma não significativa.

Segundo Jiang et al (1999a), existe uma interação entre a concentração de 1MCP e o tempo de exposição ao produto. Então, para se ter uma eficiência máxima na aplicação do produto, quanto menor o tempo de exposição maior será a concentração necessária de 1-MCP. Esses autores verificaram que em banana armazenada a $20^{\circ} \mathrm{C}$ a concentração de $100 \mathrm{~nL} . \mathrm{L}^{-1}$ de 1 -MCP durante 12 horas foi tão eficaz quanto a concentração de $1000 \mathrm{~nL} . \mathrm{L}^{-1}$ durante 1 hora. No presente experimento, provavelmente devido ao efeito da temperatura na conservação dos frutos, essa correlação não foi observada.

A perda da cor verde da casca é devido a quebra da estrutura da molécula de clorofila, envolvendo a atividade da enzima clorofilase. $\mathrm{O}$ aumento da atividade desta 
enzima está geralmente associada com a produção de etileno durante o amadurecimento do fruto (Tucker, 1993). Tem sido relatado que o 1-MCP se liga ao sítio de ligação do etileno na célula evitando a ação do mesmo sobre os processos fisiológicos de amadurecimento (Serek et al., 1995). Assim, a perda de cor verde, resultante do processo normal de amadurecimento, foi levemente retardada com a aplicação do 1-MCP apenas na concentração de $240 \mathrm{~nL} \cdot \mathrm{L}^{-1}$. A retenção do desenvolvimento da coloração da casca em frutos tratados com 1-MCP também foi verificada em ameixa (Abdi et al., 1998), banana (Golding et al., 1998), tomate (Dupille \& Sisler, 1995) e abacate (Fan et al., 2000).
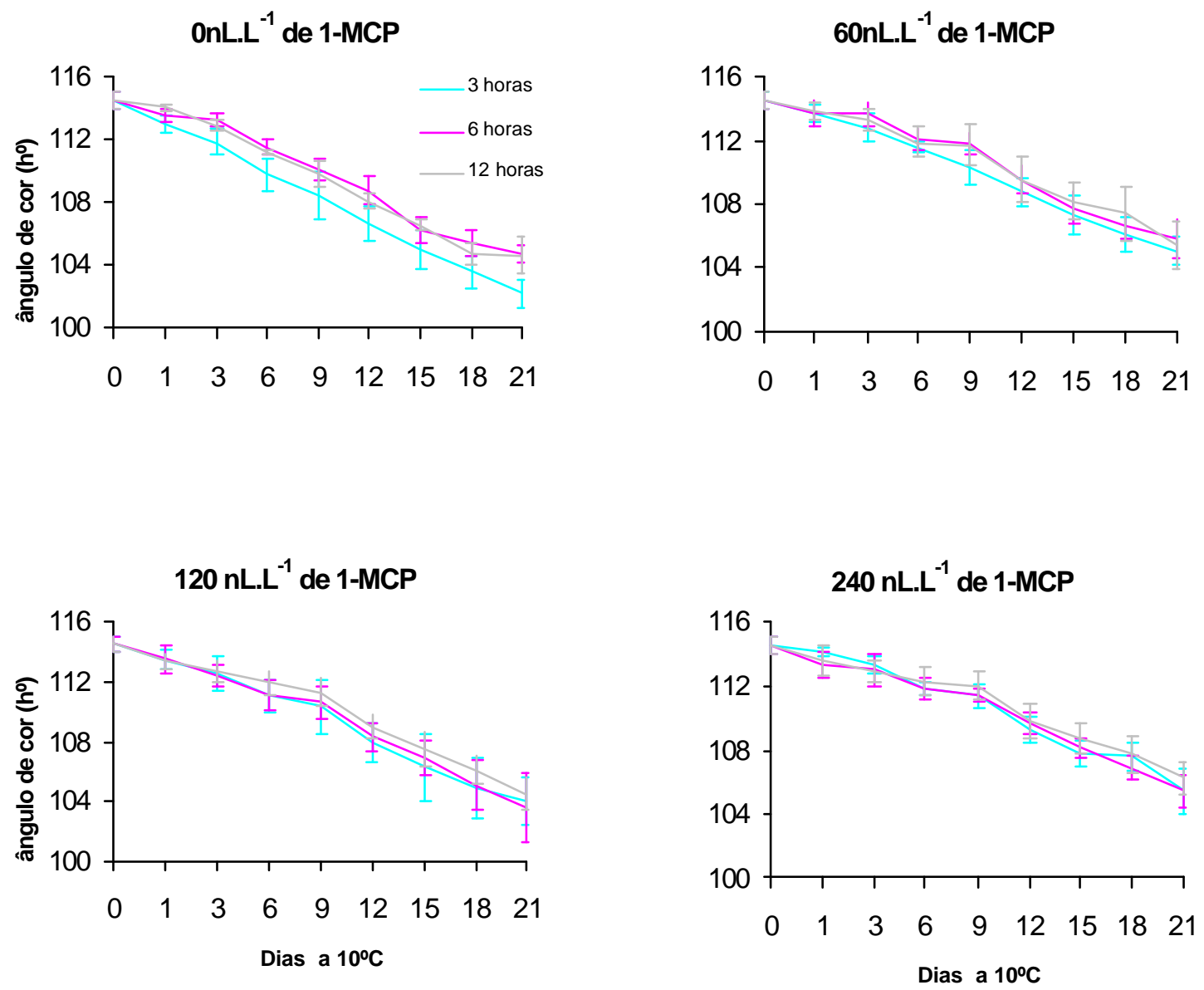

Figura 1 - Coloração da casca de goiabas 'Pedro Sato' tratadas com 1-MCP e armazenadas a $10^{\circ} \mathrm{C}$. 
Apesar de não ter havido efeito dos tratamentos nos frutos armazenados a $10^{\circ} \mathrm{C}$, esperava-se que após transferência para a condição ambiente, pudesse se observar efeitos benéficos do 1-MCP, porém isto não ocorreu, ou seja, tanto os frutos tratados quanto os não tratados tornaram-se amarelos após 2 dias a $25^{\circ} \mathrm{C}$ (Tabela 1).

Segundo Hardenburg et al., (1986) o armazenamento em temperaturas baixas é um método eficiente, que mantêm a qualidade da maioria dos produtos hortícolas, devido aos seus efeitos de redução nos processos de respiração, transpiração, produção de etileno, amadurecimento, senescência e desenvolvimento de podridões.

Quanto menor a temperatura de armazenamento maior será a concentração requerida para uma completa proteção ao etileno, devido à afinidade ao receptor do etileno ser menor do que em temperaturas mais altas (Sisler et al., 1996). Provavelmente o efeito do 1-MCP foi discreto devido à baixa temperatura de armazenamento $\left(10^{\circ} \mathrm{C}\right)$ e também devido às baixas concentrações utilizadas.

Tabela 1. Cor da casca $\left(\mathrm{h}^{\circ}\right)$ de goiabas 'Pedro Sato' tratadas com 1-MCP e armazenadas a $10^{\circ} \mathrm{C}^{1}$

\begin{tabular}{lcccc}
\hline & Sem 1-MCP & Com 1-MCP & Teste F & C.V. (\%) \\
\hline Recém-colhidas & 113,0 & 113,0 & - & - \\
14 dias a $10^{\circ} \mathrm{C}$ & 106,7 & 107,9 & n.s. & 0,95 \\
14 dias a $10^{\circ} \mathrm{C}+2$ dias a $25^{\circ} \mathrm{C}$ & 97,6 & 98,5 & n.s. & 2,1 \\
21 dias a $10^{\circ} \mathrm{C}$ & 104,6 & 105,0 & n.s. & 1,2 \\
21 dias a $10^{\circ} \mathrm{C}+2$ dias a $25^{\circ} \mathrm{C}$ & 98,0 & 98,4 & n.s. & 1,6
\end{tabular}

${ }^{1}$ Os valores são referentes à média do ângulo de cor $\left(h^{\circ}\right)$ das quatro concentrações nos três tempos de exposição

A porcentagem de frutos com podridão aumentou com 0 tempo de armazenamento a $10^{\circ} \mathrm{C}$ e principalmente após transferência para $25^{\circ} \mathrm{C}$ (Figura 2). O efeito dos tratamentos foi discreto, porém observou-se, de maneira geral, redução da incidência de podridão com o aumento da concentração de 1-MCP e do tempo de exposição ao produto. 

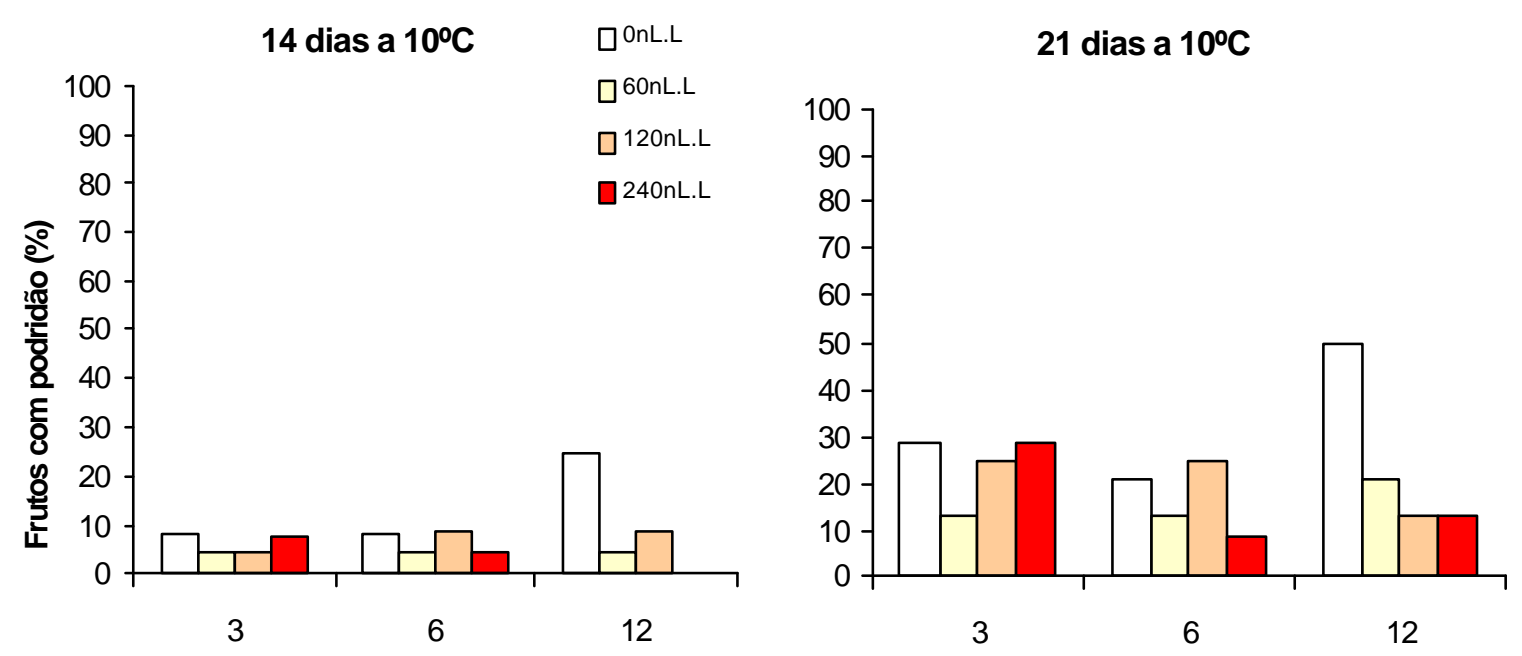

14 dias a $10^{\circ} \mathrm{C}+2$ dias a $25^{\circ} \mathrm{C}$
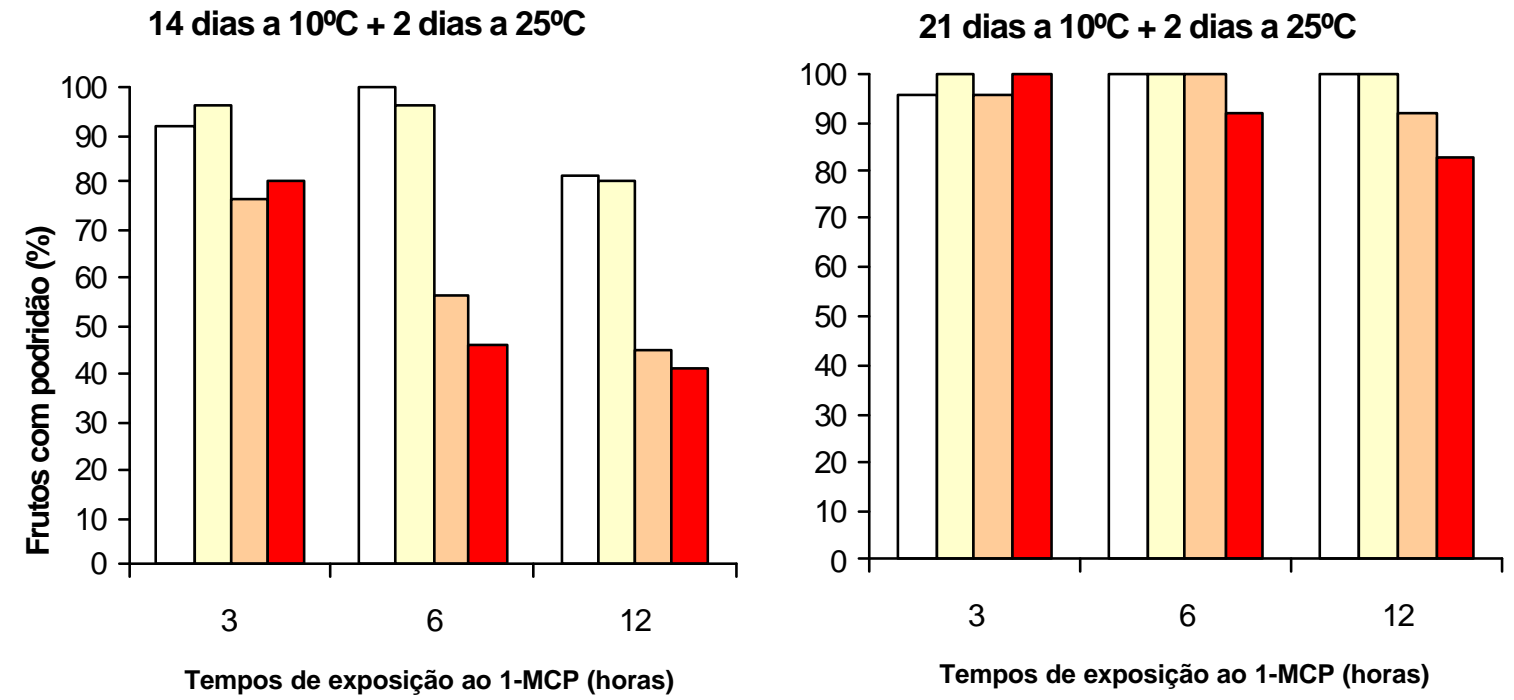

Figura 2 - Incidência de podridão em goiabas 'Pedro Sato' tratadas com 1-MCP.

Para os frutos armazenados a $10^{\circ} \mathrm{C}$ por 21 dias mais 2 dias a $25^{\circ} \mathrm{C}$, não foi verificado diferença entre os tratamentos quanto a incidência de podridão. Provavelmente, devido ao longo período de armazenamento novos sítios receptores de etileno foram sintetizados. Em goiaba, as podridões pós-colheita aumentam conforme o amadurecimento avança, sendo um dos principais problemas depreciadores da qualidade dos frutos (Jacomino, 1999). Os fungos mais freqüentemente encontrados foram 
Colletrotrichum gloesporioides, Penz e Botryodiplodia theobromae Pat. O 1-MCP não é um fungicida nem tem efeito protetor ou erradicante de patógenos; seu benefício no controle de fungos que apodrecem os frutos é indireto, pelo retardamento no amadurecimento dos frutos, o que justifica a menor incidência de podridão nos frutos tratados com 1-MCP nas concentrações de 120 e 240 nL.L ${ }^{-1}$ de 1-MCP durante os tempos de 6 ou 12 horas de exposição.

As goiabas foram colhidas com $86,1 \mathrm{~N}$ de firmeza e apresentaram acentuada redução após o amadurecimento. As goiabas armazenadas durante 14 dias a $10^{\circ} \mathrm{C}+$ 2 dias a $25^{\circ} \mathrm{C}$ apresentaram firmeza de 13,4 a $16,5 \mathrm{~N}$ e aquelas armazenadas durante 21 dias +2 dias a $25^{\circ} \mathrm{C}$ apresentaram firmeza de 6,1 a 7,0N (Tabela 2).

Os tratamentos exerceram pouca influência na manutenção da firmeza. Apenas os frutos tratados com 240nL. $\mathrm{L}^{-1}$ mantiveram-se mais firmes que os demais, quando submetidos ao menor tempo de armazenamento.

A firmeza de polpa do fruto é determinada pela força de coesão entre as pectinas. Com a evolução do amadurecimento ocorre atuação de enzimas pectinolíticas, que transformam a pectina insolúvel em solúvel e promovem o amolecimento dos frutos. A maior firmeza dos frutos tratados com $240 \mathrm{~nL} \cdot \mathrm{L}^{-1}$ de 1-MCP, está, provavelmente, associada à redução da atividade das enzimas pectinolíticas, induzida pela menor ação do etileno. Provavelmente novos sítios receptores de etileno foram sintetizados com o decorrer do armazenamento, induzindo o aumento da atividade das enzimas pectinolíticas promovendo a maior perda de firmeza nos frutos armazenados durante 21 dias.

Não houve influência dos tratamentos nos teores de acidez, sólidos solúveis e ácido ascórbico e nem na cor da polpa, independente do tempo de armazenamento a $10^{\circ} \mathrm{C}$ (Tabela 3 e 4). Estas variáveis apresentaram ambém, pouca evolução durante o amadurecimento.

Não houve influência das concentrações de $1 \mathrm{MCP}$ sobre a perda de massa dos frutos (Tabela 5). A perda de peso do fruto colhido é oriunda da respiração e transpiração. Dada a capacidade do 1-MCP em reduzir a espiração (Abdi et al., 1998; Golding et al., 1998) poderia-se esperar uma menor perda de peso nos frutos tratados. 
De fato, a respiração reduz o peso do fruto, mas numa proporção bem menor do que a transpiração, onde o 1-MCP parece não promover efeito.

Tabela 2. Firmeza da polpa de goiabas 'Pedro Sato' tratadas com 1-MCP e armazenadas durante 14 e 21 dias a $10^{\circ} \mathrm{C}$, mais 2 dias a $25^{\circ} \mathrm{C}$.

\begin{tabular}{ccc}
\hline $\begin{array}{c}\text { Concentração de 1-MCP } \\
\left(\text { nL.L } \text { - }^{-1}\right)\end{array}$ & $\begin{array}{c}14 \text { dias a } 10^{\circ} \mathrm{C} \\
+\end{array}$ & $\begin{array}{c}21 \text { dias a } 10^{\circ} \mathrm{C} \\
+\end{array}$ \\
\hline 0 & 2 dias a $25^{\circ} \mathrm{C}$ & 2 dias a $25^{\circ} \mathrm{C}$ \\
\hline 60 & $13,4 \mathrm{~b}$ & $6,1 \mathrm{a}$ \\
120 & $13,8 \mathrm{~b}$ & $6,2 \mathrm{a}$ \\
240 & $14,7 \mathrm{ab}$ & $7,0 \mathrm{a}$ \\
\hline
\end{tabular}

${ }^{1}$ Os valores são referentes à média da firmeza da polpa $(\mathrm{N})$ dos três tempos de exposição. Médias seguidas de mesma letra minúscula na coluna não diferem entre si pelo teste de Tukey $(5 \%)$. Firmeza $(\mathrm{N})$ antes dos tratamentos $=86,1$.

Tabela 3. Significância do teste F da análise de variância para os efeitos dos tratamentos, nas variáveis analisadas em goiabas 'Pedro Sato' tratadas com 1-MCP e armazenadas por 14 dias a $10^{\circ} \mathrm{C}$ mais 2 dias a $25^{\circ} \mathrm{C}$.

Variáveis analisadas

\begin{tabular}{lcccc} 
Tratamentos e interação & $\begin{array}{c}\text { ATT } \\
(\% \text { ácido } \\
\text { cítrico) }\end{array}$ & $\begin{array}{c}\text { SST } \\
\left({ }^{\circ} \text { Brix }\right)\end{array}$ & $\begin{array}{c}\text { Ácido } \\
\text { ascórbico } \\
(\mathrm{mg} / 100 \mathrm{~g})\end{array}$ & $\begin{array}{c}\text { Cor polpa } \\
\text { (croma) }\end{array}$ \\
\hline 1-MCP & --------------- & Significância de teste $\mathrm{F}^{1}$---------------- \\
Tempo (T) & n.s. & n.s. & n.s. & n.s. \\
1-MCP x T & n.s. & n.s. & n.s. & n.s. \\
Coeficiente variação (\%) & n.s. & n.s. & n.s. & n.s. \\
Caracterização $^{2}$ & 6,3 & 5,1 & 17,4 & 5,1 \\
Média final $^{5}$ & 0,55 & 7,7 & 50,7 & 31,8 \\
\hline
\end{tabular}

${ }^{1}$ n.s $=$ não significativo a $\mathrm{P} \leq 0,05$.

${ }^{2}$ média dos dados coletados antes dos tratamentos.

${ }^{3}$ média dos dados coletados no final do armazenamento. 
Tabela 4. Significância do teste $\mathrm{F}$ da análise de variância para os efeitos dos tratamentos, nas variáveis analisadas em goiabas 'Pedro Sato' tratadas com 1-MCP e armazenadas por 21 dias a $10^{\circ} \mathrm{C}$ mais 2 dias a $25^{\circ} \mathrm{C}$.

\begin{tabular}{|c|c|c|c|c|}
\hline \multirow[b]{2}{*}{ Tratamentos e interação } & \multicolumn{4}{|c|}{ Variáveis analisadas } \\
\hline & $\begin{array}{l}\text { ATT } \\
\text { (\%ácido } \\
\text { cítrico) }\end{array}$ & $\begin{array}{c}\text { SST } \\
\left({ }^{\circ} \text { Brix }\right)\end{array}$ & $\begin{array}{c}\text { Ácido } \\
\text { ascórbico } \\
(\mathrm{mg} / 100 \mathrm{~g})\end{array}$ & $\begin{array}{c}\text { Cor polpa } \\
\text { (croma) }\end{array}$ \\
\hline & \multicolumn{4}{|c|}{ - } \\
\hline 1-MCP & n.s. & n.s. & n.s. & n.s. \\
\hline Tempo (T) & n.s. & n.s. & n.s. & n.s. \\
\hline 1-MCP x T & n.s. & n.s. & n.s. & n.s. \\
\hline Coeficiente variação (\%) & 6,6 & 5,5 & 14,5 & 5,6 \\
\hline Caracterização $^{2}$ & 0,55 & 7,7 & 50,7 & 31,8 \\
\hline Média final $^{3}$ & 0,60 & 7,9 & 49,2 & 33,7 \\
\hline
\end{tabular}

n.s= não significativo a $\mathrm{P} \leq 0,05$.

${ }^{2}$ média dos dados coletados antes dos tratamentos.

${ }^{3}$ média dos dados coletados no final do armazenamento.

Tabela 5. Perda de massa de goiabas 'Pedro Sato' tratadas com 1-MCP e armazenadas durante 21 dias a $10^{\circ} \mathrm{C}^{1}$.

\begin{tabular}{ccccc}
\hline $\begin{array}{c}\text { Concentração de 1-MCP } \\
\left(\text { (nL.L }{ }^{-1}\right)\end{array}$ & \multicolumn{4}{c}{ Tempo de exposição (horas) } \\
& $\mathbf{3}$ & $\mathbf{6}$ & $\mathbf{1 2}$ & Médias \\
\hline 0 & 3,6 & 3,0 & 3,2 & $3,3 \mathrm{a}$ \\
60 & 3,5 & 2,9 & 3,3 & $3,2 \mathrm{a}$ \\
120 & 3,8 & 2,9 & 3,2 & $3,3 \mathrm{a}$ \\
240 & 3,8 & 3,3 & 3,2 & $3,4 \mathrm{a}$ \\
Médias & $3,7 \mathrm{~A}$ & $3,0 \mathrm{~A}$ & $3,2 \mathrm{~A}$ & \\
\hline
\end{tabular}

1) Médias seguidas de mesma letra minúscula na coluna e maiúscula na linha não diferem entre si pelo teste de Tukey (5\%); coeficiente de variação $=21,4 \%$. 
Pelo presente experimento verificou-se pouco efeito do 1-MCP na conservação das goiabas armazenadas a $10^{\circ} \mathrm{C}$, apesar do pequeno efeito na manutenção da firmeza e redução da incidência de podridão.

Estes resultados devem-se, provavelmente, ao fato do experimento ter sido conduzido sob refrigeração.

Pode ser que maiores concentrações deste regulador sejam necessárias para produzir os efeitos desejados nestas condições.

\subsection{Conclusão}

Pelos resultados obtidos conclui-se que:

$\checkmark$ O 1-MCP não foi eficiente em retardar o amadurecimento de goiabas 'Pedro Sato' armazenadas a $10^{\circ} \mathrm{C}$, nas concentrações e tempos de exposição estudados. 


\section{CONCENTRAÇÕES DE 1-METILCICLOPROPENO (1-MCP) E TEMPOS DE EXPOSIÇÃO NA CONSERVAÇÃO DE GOIABAS 'PEDRO SATO' EM CONDIÇÃO AMBIENTE}

\section{Resumo}

Goiabas 'Pedro Sato' foram tratadas com 0, 100, 300 e 900 nL.L - $^{-1}$ de 1metilciclopropeno durante 3,6 e 12 horas e armazenadas a $25^{\circ} \mathrm{C}$ até atingirem o completo amadurecimento. Foram analisadas as seguintes variáveis: coloração da casca, coloração da polpa, perda de massa, firmeza da polpa, acidez total titulável (ATT), teor de ácido ascórbico, teor de sólidos solúveis totais (SST), incidência de podridões e respiração. As goiabas não tratadas puderam ser conservadas por 5 dias; enquanto aquelas tratadas, por até 9 dias. As concentrações de 100 e 300 nL.L $L^{-1}$ de 1-MCP foram ineficientes no tempo de exposição de 3 horas, mas prolongaram a conservação nos tratamentos por 6 ou 12 horas. Os tratamentos 300 nL.L ${ }^{-1}$ de 1-MCP durante 6 ou 12 horas e 900 nL.L ${ }^{-1}$ de 1 -MCP durante 3 horas promoveram os melhores resultados. Os tratamentos 900 nL.L ${ }^{-1}$ de 1 -MCP durante 6 ou 12 horas não foram adequados, por impedirem o amadurecimento das goiabas.

Palavras-chave: Psidium guajava, 1-metilciclopropeno, conservação, concentração e tempo de exposição 


\section{CONCENTRATIONS AND EXPOSURE TIMES OF 1-MCP IN THE CONSERVATION OF 'PEDRO SATO' GUAVAS STORED AT ROOM TEMPERATURE}

\section{Summary}

'Pedro Sato' guava fruits were treated with $0,100,300$ or 900 nL.L ${ }^{-1}$ of 1 methylciclopropene (1-MCP) for 3,6 or 12 hours and stored at $25^{\circ} \mathrm{C}$ until their complete ripening. Skin color, pulp color, weight loss, firmness, total titrable acidity, ascorbic acid, total soluble solids and decay incidence and respiration rate were evaluated. All of the treated fruits could be stored, for up to 9 days, while the non treated guava fruits for only 5 days. The 100 and 300 nL.L ${ }^{-1}$ of $1-\mathrm{MCP}$ concentration were inefficient for the 3 hours of exposure time, but improved conservation of the 6 or 12 hours treatments. The 300 nL.L $\mathrm{L}^{-1}$ of 1 -MCP treatment for 6 or 12 hours and the $900 \mathrm{~nL} . \mathrm{L}^{-1}$ of $1-\mathrm{MCP}$ treatment for 3 hours promoted the best results. Treatment with 900 nL.L $\mathrm{L}^{-1}$ 1-MCP for 6 or 12 hours were not enough to avoid the ripening of the guava fruits.

Key-words: Psidium guajava, 1-methylciclopropene, conservation, concentration and exposure time

\subsection{Introdução}

A goiaba é uma fruta muito popular no Brasil e constitui uma elevada fonte de vitamina C para o ser humano. Apresenta excelentes características organolépticas e alto rendimento em polpa, tornando-a adequada tanto para o consumo in natura quanto para a industrialização (Carvalho, 1994).

Sendo uma fruta climatérica a goiaba, apresenta rápido amadurecimento após a colheita, o que a torna altamente perecível. Sua vida de prateleira é de 2 a 3 dias sob condição ambiente (Carvalho, 1994; Durigan, 1997). Dada essa alta perecibilidade, o controle do amadurecimento é fundamental para o aumento na vida útil após a colheita, visando o mercado interno e exportação de frutas. 
Os principais fatores depreciadores da qualidade pós-colheita de goiabas são a rápida perda da coloração verde da casca (Jacomino, 1999) e elevada incidência de podridões (Ali \& Lazan, 1997), além do amolecimento excessivo, murchamento dos frutos e perda de brilho.

A preservação da goiaba em temperatura ambiente é desejável, uma vez que a quase totalidade dos frutos comercializados ao nível de varejo, no Brasil, encontram-se sem refrigeração. $\mathrm{O}$ aumento de sua vida útil nessas condições pode facilitar o transporte a longas distâncias e ampliar o período de comercialização.

$\mathrm{O}$ etileno $\left(\mathrm{C}_{2} \mathrm{H}_{4}\right)$ está envolvido na aceleração do amadurecimento e senescência de frutos climatéricos. Em um determinado estádio da maturação, o etileno presente nos espaços intercelulares se liga ao seu receptor na célula e desencadeia uma série de eventos que culminam com o amadurecimento e senescência do fruto (Burg \& Burg, 1967, Lelièvre et al. 1997). Tem sido verificado que a inibição da ligação do etileno ao seu receptor pode reduzir a produção e a ação do mesmo e, com isso, retardar o amadurecimento e a senescência de frutos climatéricos.

O 1-metilciclopropeno (1-MCP) é um produto bloqueador da ação do etileno (Serek et al., 1995) e tem sido utilizado com sucesso na conservação de flores, hortaliças e frutos. Tem-se verificado um aumento na vida útil destes produtos de forma bastante efetiva, mantendo uma boa qualidade. A concentração de 1-MCP necessária para apresentar efeito no bloqueio da ação do etileno varia conforme a espécie/cultivar, estádio de maturação, temperatura de exposição (Rupasingue et al., 2000), interação concentração x tempo de exposição e produção de novos receptores de etileno (Watkins et al., 2000).

O 1-MCP é mais eficaz quando as frutas e hortaliças são expostas ao produto por pelo menos 12 horas, sob condições de temperatura mais alta $\left(>13^{\circ} \mathrm{C}\right)$ (Boletim Técnico, Rohm and Haas Company, s.d.).

Considerando que o tempo de exposição de 12 horas é um período bastante longo de exposição ao produto não sendo viável o seu uso pelo produtor, o objetivo do presente trabalho foi verificar o efeito de altas concentrações e tempos de exposição de 1-MCP no amadurecimento e senescência de goiaba armazenada sob condição ambiente. 


\subsection{Material e Métodos}

Goiabas 'Pedro Sato' foram colhidas em pomar comercial localizado no município de Vista Alegre do Alto (SP), e transportadas ao Laboratório de Pós-colheita de Produtos Hortícolas do Departamento de Produção Vegetal da ESALQ/USP, em Piracicaba (SP). Foram utilizados frutos sem defeitos, em estádio de maturação caracterizado pela mudança da cor da casca de verde-escuro para verde-claro, com massa de $153 \pm 10 \mathrm{~g}$.

Os frutos foram selecionados e submetidos aos tratamentos com $\mathrm{Smartfresh}^{\circledR}$, na formulação pó molhável, contendo $0,14 \%$ de i.a. 1-MCP. Foram utilizadas as seguintes concentrações de 1-MCP: 0, 100, 300 e 900 nL.L $\mathrm{L}^{-1}$. A aplicação constou da colocação dos frutos em câmara hermética e exposição ao produto por período de 3, 6 e 12 horas e temperatura de $24-25^{\circ} \mathrm{C}$. Para produzir as concentrações desejadas de 1-MCP no interior da câmara, quantidade pré-determinada de Smartfresh $^{\circledR}$, foi colocada em frasco com tampa $\left(0,16 \mathrm{~g}\right.$ de Smartfresh $^{\circledR}$ representam $100 \mathrm{~nL} . \mathrm{L}^{-1}$ de $1-\mathrm{MCP}$ em $\left.1 \mathrm{~m}^{3}\right)$. Adicionou-se $20 \mathrm{ml}$ de água destilada a $50^{\circ} \mathrm{C}$ e agitourse o frasco até a completa dissolução do produto. O frasco foi aberto no interior da câmara, a qual foi fechada imediatamente para evitar a perda do gás. Após os tratamentos, as câmaras foram abertas e os frutos foram colocados em condição ambiente $\left(25^{\circ}\right)$.

$\mathrm{O}$ delineamento experimental adotado foi inteiramente casualizado, em esquema fatorial. Os fatores estudados foram concentração de 1-MCP e tempo de exposição ao produto. Foram utilizadas quatro repetições por tratamento com seis frutos por parcela, totalizando 375 frutos.

Os resultados das análises foram submetidos a análise do desvio padrão. As diferenças entre dois tratamentos maior que a soma de dois desvios padrões foram consideradas significativas.

As variáveis analisadas foram: a) Coloração da casca e da polpa: determinada através de colorímetro Minolta Croma Meter CR-300, e os resultados expressos em ângulo de cor $\left({ }^{\circ} h\right)$ para cor da casca e croma para cor da polpa. $\mathrm{O}$ h define a coloração básica, onde $0^{\circ}=$ vermelho, $90^{\circ}=$ amarelo e $180^{\circ}=$ verde. $\mathrm{O}$ croma define a saturação e 
intensidade da cor definida pelo $\mathrm{h}^{0}$ (McGuire, 1992). Para cor da casca, realizaram-se duas leituras em lados opostos da região equatorial e para cor da polpa, uma leitura no centro da região placentária, após corte transversal; b) Perda de peso: por diferença, em $\%$, entre a massa inicial e final da repetição; c) Firmeza da polpa: determinada com penetrômetro digital, ponteira $8 \mathrm{~mm}$, tomando-se duas leituras por fruta, em lados opostos da região equatorial e os resultados expressos em Newton; d)Acidez total titulável (ATT): determinada por titulometria de acordo com metodologia de Carvalho et al. (1990) e os resultados expressos em \% de ácido cítrico; e)Teor de ácido ascórbico: determinado por titulometria de acordo com metodologia descrita por Carvalho et al. (1990), sendo os resultados expressos em mg de ácido ascórbico por 100g de polpa; f)Teor de sólidos solúveis totais (SST): utilizando-se uma amostra centrifugada da fruta e determinada através de leitura direta em refratômetro digital Atago modelo Palete 101, expressando os resultados em ${ }^{\circ}$ Brix; g)Incidência de podridões: avaliada pela contagem do número de frutos afetados, sendo os resultados expressos em porcentagem e h) Taxa respiratória: para esta determinação, foram utilizados 2 frutos com massa e volume conhecidos e foram incubados em frascos herméticos com capacidade para 1700ml. Após uma hora determinou-se a concentração de $\mathrm{CO}_{2}$ no interior dos frascos utilizandose de um analisador de gases PBI Dansensor modelo Check Mate. A taxa respiratória foi calculada e expressa em $\mathrm{mgCO}_{2} \cdot \mathrm{kg}^{-1} \cdot \mathrm{h}^{-1}$. Utilizaram-se 5 repetições para cada tratamento.

A taxa respiratória e a coloração da casca foram analisadas diariamente. As demais características foram avaliadas no início do experimento e no completo amadurecimento dos frutos.

Os resultados obtidos foram submetidos à analise de variância (teste F) e, em caso de significância, as médias foram comparadas pelo teste de Tukey ao nível de 5\% de probabilidade. 


\subsection{Resultados e Discussão}

As goiabas foram armazenadas a $25^{\circ} \mathrm{C}$ até a máxima vida de prateleira (Tabela 1). Este tempo foi determinado levando-se em conta o estádio de amadurecimento (completamente maduras) ou o estado de conservação (limite de aceitabilidade). As goiabas foram consideradas totalmente maduras quando apresentaram cor da casca totalmente amarela $\left(h^{\circ} 100\right.$ ), entretanto, os frutos dos tratamentos $300 \mathrm{~nL} \cdot \mathrm{L}^{-1} / 12 \mathrm{~h}$, 900nL. $\mathrm{L}^{-1} / 3 \mathrm{~h}, 900 \mathrm{~nL} \cdot \mathrm{L}^{-1} / 6 \mathrm{~h}$ e $900 \mathrm{~nL} \cdot \mathrm{L}^{-1} / 12 \mathrm{~h}$, apesar de não atingirem o ângulo de cor $\left(h^{\circ}\right)$ 100, foram destruídos devido a presença de botryodiploidia. O limite de aceitabilidade foi determinado pela aparência. Desta forma, goiabas com murchamento visível (perda de massa 10\%) foram consideradas inaceitáveis para o consumo. As concentrações de $100 \mathrm{~nL} . \mathrm{L}^{-1} / 12 \mathrm{~h}, \quad 300 \mathrm{~nL} \cdot \mathrm{L}^{-1} / 6 \mathrm{~h}, \quad 300 \mathrm{~nL} \cdot \mathrm{L}^{-1} / 12 \mathrm{~h}$ e $900 \mathrm{~nL} \cdot \mathrm{L}^{-1} / 3$ horas proporcionaram uma melhor retenção no amadurecimento dos frutos, permitindo maior período de armazenamento (8 a 9 dias) (Tabela 1).

Tabela 1. Tempo máximo de conservação de goiabas 'Pedro Sato' tratadas com 1MCP e armazenadas a $25^{\circ} \mathrm{C}$.

\begin{tabular}{cccc}
\hline $\begin{array}{c}\text { Concentração de } \\
\text { 1-MCP }\left(n L . L^{-1}\right)\end{array}$ & $\mathbf{3}$ & $\mathbf{6}$ & $\mathbf{1 2}$ \\
\hline & -1 empo de exposição (horas) & \\
0 & 5 & 5 & 5 \\
100 & 6 & 7 & 8 \\
300 & 6 & 9 & 9 \\
900 & 9 & 10 & 11 \\
\hline
\end{tabular}

O 1-MCP foi eficiente em retardar o desverdecimento da casca dos frutos. De maneira geral, a retenção da cor verde foi maior, quanto maior a concentração e o tempo de exposição ao regulador vegetal (Figura 1). Os frutos não tratados apresentavam-se completamente amarelos no $5^{\circ}$ dia após o início do experimento. Os frutos tratados com 
100 nL. $\mathrm{L}^{-1}$ ou $300 \mathrm{~nL} . \mathrm{L}^{-1}$ durante 3 horas, apresentaram pouco incremento na retenção da cor da casca, quando comparados aos frutos não tratados. Já os frutos tratados durante 6 ou 12 horas, nestas mesmas concentrações apresentaram significativa retenção da cor da casca. Estes frutos tornaram-se completamente amarelos entre o $7^{\circ}$ e o $9^{\circ}$ dia após o tratamento. Os frutos tratados com 900 nL.L $\mathrm{L}^{-1}$ durante 3 horas também tornaram-se amarelos no $9^{\circ}$ dia após o tratamento e aqueles tratados durante 6 ou 12 horas não amareleceram.
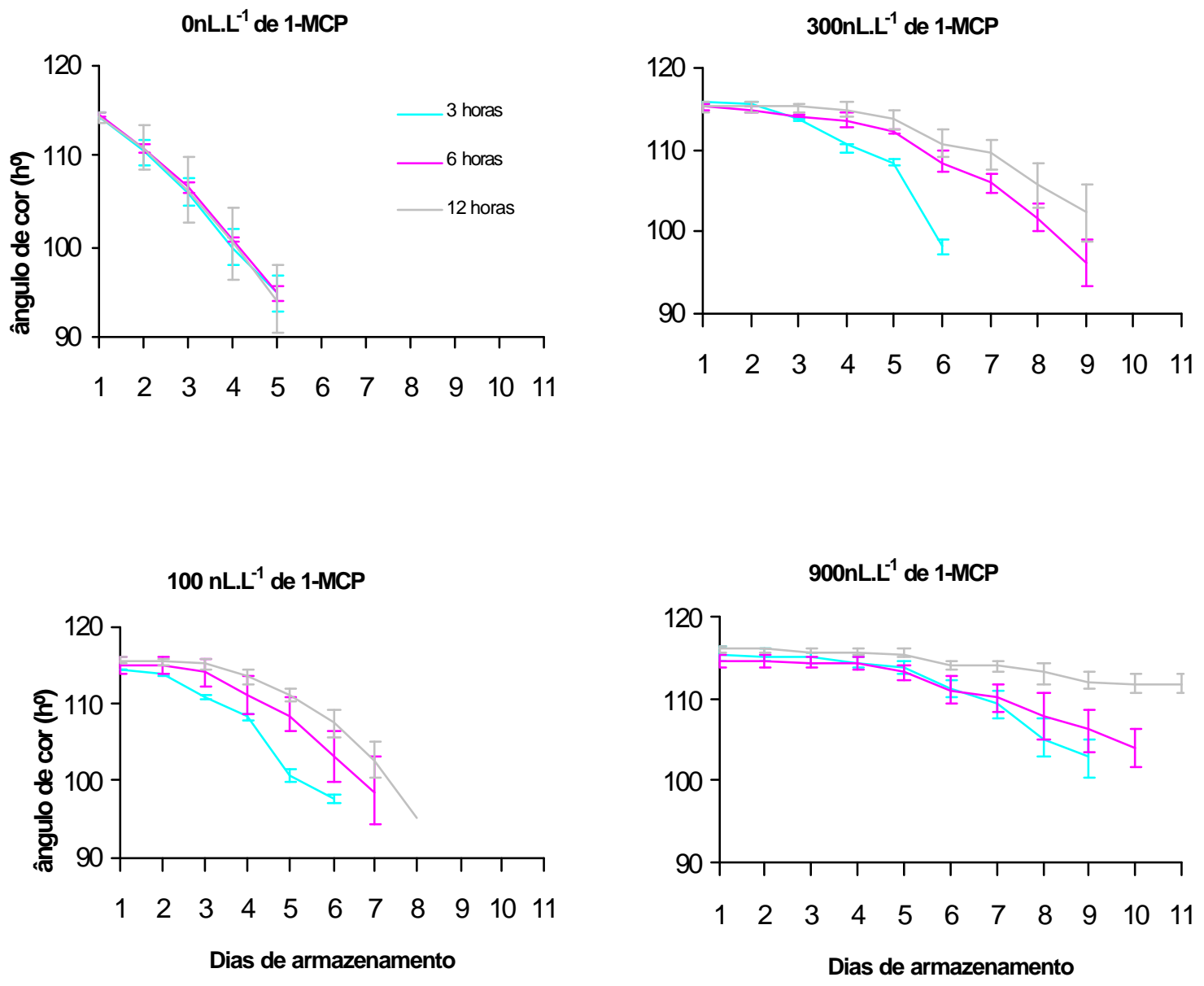

Figura 1 - Coloração da casca de goiabas 'Pedro Sato' tratadas com 1-MCP e armazenadas a $25^{\circ} \mathrm{C}$ 
Observando a cor da casca dos frutos no $5^{\circ}$ dia de armazenamento verifica-se que todos os tratamentos apresentaram efeito positivo, quando comparados ao controle (Tabela 2 e Figura 2). Verificou-se também que com o aumento da concentração de $1-$ MCP, o tempo de exposição necessário para apresentar efeito na retenção da coloração da casca diminuiu. Nos frutos tratados com 100 nL.L ${ }^{-1}$ de 1-MCP houve interferência do tempo de exposição, sendo que o período de 12 horas proporcionou a melhor retenção da cor verde da casca dos frutos. Para os frutos tratados com 300 nL.L ${ }^{-1}$ de 1-MCP, os tempos de 6 e 12 horas proporcionaram resultados equivalentes entre si e superiores ao tempo de 3 horas. Entretanto, para os frutos tratados com 900 nL.L $\mathrm{L}^{-1}$ de 1-MCP não foi observada diferença entre os tempos de exposição, sendo o tempo de exposição de 3 horas tão eficiente quanto 6 ou 12 horas. Observou-se que os frutos tratados com 900 nL. $\mathrm{L}^{-1}$ de 1-MCP por 3 horas apresentaram a mesma coloração da casca que os frutos tratados com 300 nL.L - $^{-1}$ de 1 -MCP por 12 horas.

Essa relação entre concentração e tempo de exposição também foi verificada em trabalhos com banana (Jiang et al. 1999) e abacate (Jeong et al.,2002).

Tabela 2. Coloração da casca de goiabas 'Pedro Sato' tratadas com 1-MCP e armazenadas a $25^{\circ} \mathrm{C}$, durante 5 dias $^{1}$.

\begin{tabular}{cccc}
\hline $\begin{array}{c}\text { Concentração de } \\
1-\mathrm{MCP}\left(\mathrm{nL} \cdot \mathrm{L}^{-1}\right)\end{array}$ & $\mathbf{3}$ & $\mathbf{6}$ & $\mathbf{1 2}$ \\
\hline & - & Tempo de exposição (horas) \\
0 & $94,9 \mathrm{~d} \mathrm{~A}$ & $94,9 \mathrm{c} \mathrm{A}$ & $94,1 \mathrm{c} \mathrm{A}$ \\
100 & $100,8 \mathrm{c} \mathrm{C}$ & $108,5 \mathrm{~b} \mathrm{~B}$ & $111,2 \mathrm{~b} \mathrm{~A}$ \\
300 & $108,5 \mathrm{~b} \mathrm{~B}$ & $112,1 \mathrm{a} \mathrm{A}$ & $113,8 \mathrm{ab} \mathrm{A}$ \\
900 & $113,8 \mathrm{a} \mathrm{A}$ & 113,3 a A & 115,6 a A \\
\hline
\end{tabular}

${ }^{1)}$ Médias seguidas de mesma letra minúscula na coluna e maiúscula na linha não diferem entre si pelo teste de Tukey $(5 \%)$; coeficiente de variação $=1,4 \%$; Ângulo de cor $\left({ }^{\circ} \mathrm{h}\right)$ antes dos tratamentos $=116,5$.

A perda da cor verde é devido a quebra da estrutura da molécula de clorofila, envolvendo a atividade da enzima clorofilase. O aumento da atividade desta enzima está geralmente associada com a produção de etileno durante o amadurecimento do fruto 
(Tucker, 1993). O 1-MCP se liga ao sítio de ligação do etileno na célula evitando a ação do mesmo sobre os processos fisiológicos de amadurecimento (Serek et al., 1995). Assim a perda da cor verde, resultante do processo normal de amadurecimento, foi retardada com a aplicação do 1-MCP. A retenção do desenvolvimento da coloração da casca em frutos tratados com 1-MCP também foi verificada em ameixa (Abdi et al., 1998), banana (Golding et al., 1998), tomate (Dupille \& Sisler, 1995), abacate (Fan et al, 2000) e mamão (Jacomino et al., 2002).

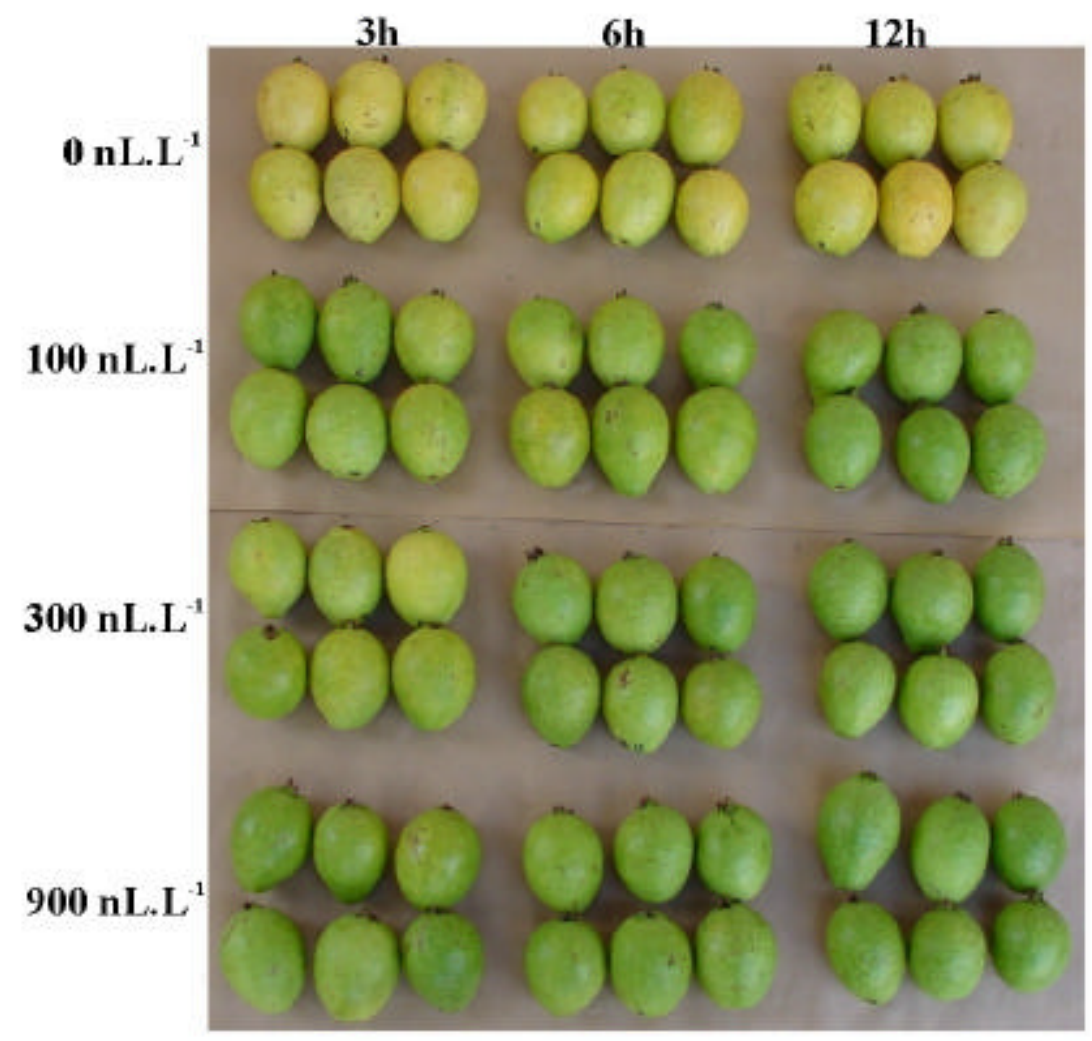

Figura 2 - Coloração da casca de goiabas 'Pedro Sato' tratadas com 1-MCP e armazenadas a $25^{\circ} \mathrm{C}$, durante 5 dias. 
A polpa dos frutos, na região placentária, apresentava-se cor-de-rosa quando estes foram colhidos (croma $=32,3$ ) e tornou-se vermelha intensa ao final do amadurecimento (croma $=40,6$ a 42,9). O croma indica a variação na intensidade das cores, sendo maior, quanto mais vívida a cor.

A coloração da polpa dos frutos, quando estes alcançaram o completo amadurecimento, não foi influenciada pelo tempo de exposição (Tabela 3). Houve evolução na intensidade da coloração da polpa em todos os tratamentos. Nos frutos tratados com 900 nL.L $\mathrm{L}^{-1}$ de 1-MCP durante 12 horas, observou-se evolução da cor da polpa somente na região placentária, uma vez que a coloração da periderme se manteve semelhante à dos frutos recém-colhidos (Figura 3). Provavelmente, o 1-MCP não atingiu a região placentária dos frutos.

Tabela 3. Coloração da polpa de goiabas 'Pedro Sato' tratadas com 1-MCP e armazenadas a $25^{\circ} \mathrm{C}$, até o completo amadurecimento.

\begin{tabular}{|c|c|c|c|}
\hline \multirow{2}{*}{$\begin{array}{l}\text { Concentração de } \\
\text { 1-MCP }\left(n L . L^{-1}\right)\end{array}$} & \multicolumn{3}{|c|}{ Tempo de exposição (horas) } \\
\hline & 3 & 6 & 12 \\
\hline & \multicolumn{3}{|c|}{--- } \\
\hline 0 & 41,4 a A & $40,8 \mathrm{bc} \mathrm{A}$ & $41,4 \mathrm{ab} \mathrm{A}$ \\
\hline 100 & 42,6 a $\mathrm{A}$ & $42,2 \mathrm{ab} \mathrm{A}$ & $41,7 \mathrm{ab} \mathrm{A}$ \\
\hline 300 & 41,6 a $\mathrm{A}$ & 42,9 a A & 42,7 a A \\
\hline 900 & 41,5 a $\mathrm{A}$ & $40,7 \mathrm{c} \mathrm{A}$ & 40,6 b A \\
\hline
\end{tabular}

${ }^{1)}$ Médias seguidas de mesma letra minúscula na coluna e maiúscula na linha não diferem entre si pelo teste de Tukey (5\%); coeficiente de variação = 1,9\%; Cor da polpa (croma) antes dos tratamentos = 32,3.

A firmeza da polpa dos frutos recém-colhidos foi de $132,5 \mathrm{~N}$ e após o amadurecimento atingiu valores entre 16,2 e $22,3 \mathrm{~N}$. A maioria dos tratamentos não prejudicou a evolução da firmeza dos frutos, uma vez que ao final do amadurecimento, não diferiram do controle (Tabela 4). Apenas os frutos tratados com 900 nL.L $L^{-1}$ de 1 MCP durante 6 ou 12 horas continuaram bastante firmes, entretanto, não amadureceram. A firmeza de polpa do fruto é determinada pela força de coesão entre as pectinas. Com a 
evolução do amadurecimento ocorre atuação de enzimas pectinolíticas, que transformam a pectina insolúvel em solúvel e promovem o amolecimento dos frutos. O amolecimento dos frutos é um dos processos do amadurecimento mais sensíveis ao etileno (Lelièvre et al., 1997).

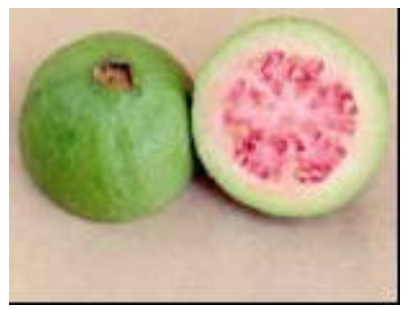

Caracterização

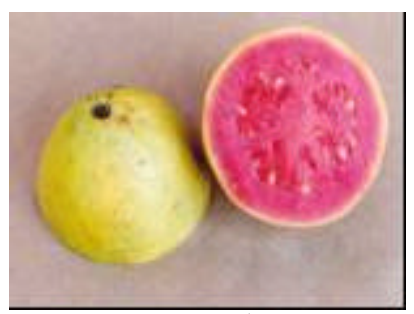

$100 \mathrm{~nL} \cdot \mathrm{L}^{-1} / 3 \mathrm{~h}$

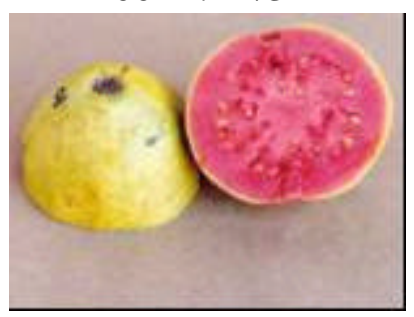

$300 n L \cdot L^{-1} / 3 h$

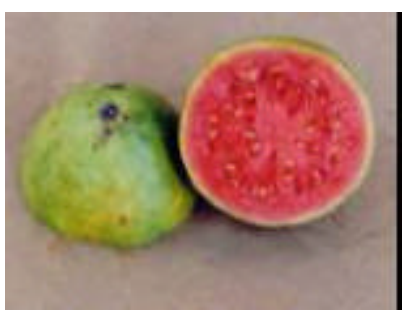

$900 \mathrm{~nL} \cdot \mathrm{L}^{-1} / 3 \mathrm{~h}$

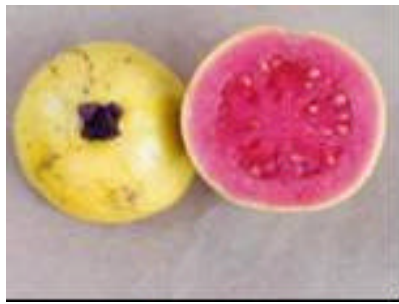

Controle $\left(0 \mathrm{~nL} \cdot \mathrm{L}^{-1}\right)$

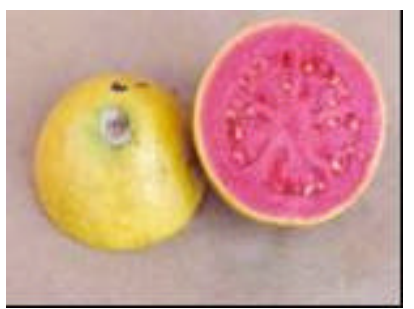

$100 \mathrm{~nL} \cdot \mathrm{L}^{-1} / 6 \mathrm{~h}$

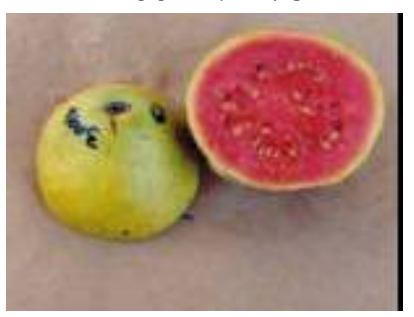

$300 n L \cdot L^{-1} / 6 h$

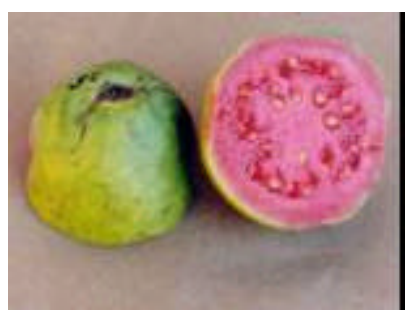

$900 \mathrm{~nL} \cdot \mathrm{L}^{-1} / 6 \mathrm{~h}$

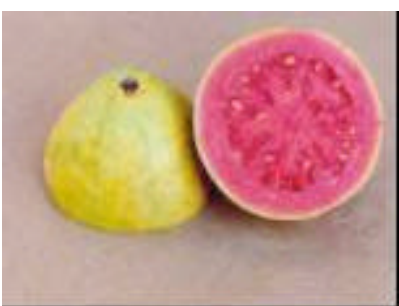

$100 \mathrm{~nL} \cdot \mathrm{L}^{-1 / 12 \mathrm{~h}}$

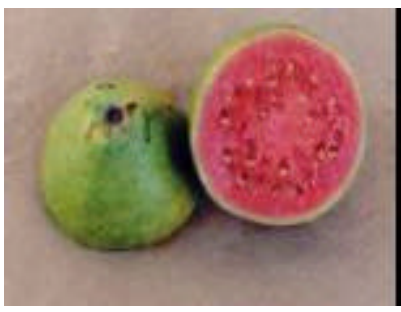

$300 \mathrm{~nL} \cdot \mathrm{L}^{-1} / 12 \mathrm{~h}$

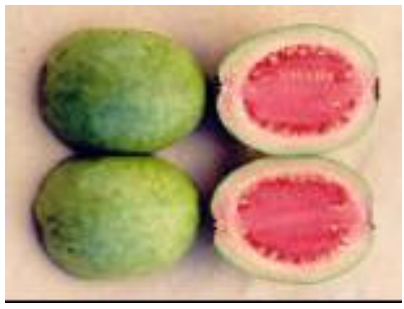

$900 \mathrm{~nL} \cdot \mathrm{L}^{-1} / 12 \mathrm{~h}$

Figura 3 - Coloração da polpa de goiabas 'Pedro Sato' tratadas com 1-MCP e armazenadas a $25^{\circ} \mathrm{C}$, até o completo amadurecimento. 
Tabela 4. Firmeza da polpa de goiabas 'Pedro Sato' tratadas com 1-MCP e armazenadas a $25^{\circ} \mathrm{C}$, até o completo amadurecimento ${ }^{1}$.

\begin{tabular}{cccc}
\hline $\begin{array}{c}\text { Concentração de } \\
1-\mathrm{MCP}\left(\mathrm{nL} \cdot \mathrm{L}^{-1}\right)\end{array}$ & $\mathbf{3}$ & Tempo de exposição (horas) \\
\hline & & $\mathbf{6}$ & $\mathbf{1 2}$ \\
\hline 0 & 22,3 a A & $22,1 \mathrm{~b} \mathrm{~A}$ & $22,2 \mathrm{~b} \mathrm{~A}$ \\
300 & 20,6 a A & $16,3 \mathrm{~b} \mathrm{~A}$ & 19,5 b A \\
900 & 23,0 a A & 16,2 b A & 18,1 b A \\
\hline
\end{tabular}

\footnotetext{
${ }^{1)}$ Médias seguidas de mesma letra minúscula na coluna e maiúscula na linha não diferem entre si pelo teste de Tukey $(5 \%)$; coeficiente de variação $=18,3 \%$; Firmeza da polpa $(\mathrm{N})$ antes dos tratamentos $=$ 132,5 .
}

De maneira geral, os frutos tratados com 900 nL.L $\mathrm{L}^{-1}$ de 1-MCP apresentaram maior teor de ácido cítrico durante o armazenamento, provavelmente devido à retenção do amadurecimento (Tabela 5). Fan et al. (2002; 2000), também observaram, em pêras e em damascos tratados com 1-MCP, menor perda da acidez durante o armazenamento.

Os frutos tratados com 1-MCP apresentaram maior perda de massa, provavelmente devido ao maior período de armazenamento (Tabela 6). A perda de massa do fruto colhido é oriunda da respiração e da transpiração (Hardenburg et al, 1986). Como o 1-MCP reduziu a respiração dos frutos tratados, provavelmente essa perda foi devido à transpiração do fruto, onde o 1-MCP parece não promover efeito. Em goiaba, tratamentos complementares ao 1-MCP poderiam ser testados com o objetivo de evitar a transpiração excessiva do fruto, como o uso de cera ou outros anti-transpirantes, para auxiliar no prolongamento do período de comercialização.

O teor de sólidos solúveis totais (SST) e o teor de ácido ascórbico não foram influenciados pelo 1-MCP. O SST variou de 10,0 a 10,8 ${ }^{\circ}$ Brix e o teor de ácido ascórbico variou de 52 a $55 \mathrm{mg} / 100 \mathrm{~g}$, ao final do completo amadurecimento dos frutos. 
Tabela 5. Acidez total titulável (ATT) de goiabas 'Pedro Sato' tratadas com 1-MCP e armazenadas a $25^{\circ} \mathrm{C}$, até o completo amadurecimento ${ }^{1}$.

\begin{tabular}{|c|c|c|c|}
\hline Concentração de & \multicolumn{3}{|c|}{ Tempo de exposição (horas) } \\
\hline $1-\mathrm{MCP}\left(\mathrm{nL} . \mathrm{L}^{-1}\right)$ & 3 & 6 & 12 \\
\hline \multicolumn{4}{|c|}{ - } \\
\hline 0 & $0,72 \mathrm{~b} \mathrm{~A}$ & $0,74 \mathrm{~b} \mathrm{~A}$ & $0,74 \mathrm{~b} \mathrm{~A}$ \\
\hline 100 & $0,73 \mathrm{~b} \mathrm{~A}$ & $0,76 \mathrm{~b} \mathrm{~A}$ & $0,80 \mathrm{~b} \mathrm{~A}$ \\
\hline 300 & $0,77 \mathrm{~b} A$ & $0,78 \mathrm{ab} \mathrm{A}$ & $0,81 \mathrm{~b} \mathrm{~A}$ \\
\hline 900 & 0,84 a B & 0,84 a B & 0,94 a $A$ \\
\hline
\end{tabular}

1) Médias seguidas de mesma letra minúscula na coluna e maiúscula na linha não diferem entre si pelo teste de Tukey (5\%); coeficiente de variação = 5,2\%; ATT (\% ácido cítrico) antes dos tratamentos $=0,73$.

Tabela 6. Perda de massa em goiabas 'Pedro Sato' tratadas com 1-MCP e armazenadas a $25^{\circ} \mathrm{C}$, até o completo amadurecimento ${ }^{1}$.

\begin{tabular}{cccc}
\hline $\begin{array}{c}\text { Concentração de } \\
1 \text {-MCP }\left(\mathrm{nL} \cdot \mathrm{L}^{-1}\right)\end{array}$ & $\mathbf{3}$ & Tempo de exposição (horas) \\
& & $\mathbf{6}$ & $\mathbf{1 2}$ \\
\hline 0 & $5,3 \mathrm{c} \mathrm{A}$ & $5,2 \mathrm{~d} \mathrm{~A}$ & $6,1 \mathrm{c} \mathrm{A}$ \\
100 & $9,9 \mathrm{ab} \mathrm{A}$ & $9,0 \mathrm{c} \mathrm{A}$ & $10,3 \mathrm{~b} \mathrm{~A}$ \\
300 & $7,4 \mathrm{bc} \mathrm{B}$ & $12,9 \mathrm{~b} \mathrm{~A}$ & $11,8 \mathrm{~b} \mathrm{~A}$ \\
900 & 11,9 a B & $16,1 \mathrm{a} \mathrm{A}$ & $15,2 \mathrm{a} \mathrm{A}$ \\
\hline
\end{tabular}

${ }^{1)}$ Médias seguidas de mesma letra minúscula na coluna e maiúscula na linha não diferem entre si pelo teste de Tukey (5\%); coeficiente de variação $=13,6 \%$.

Neste experimento, provavelmente devido às condições climáticas às quais os frutos foram submetidos no campo (falta de chuva e baixa temperatura), não foi observado presença de antracnose nos mesmos. Detectou-se, apenas, alguns frutos afetados por Botryodiplodia, sem relação com os tratamentos. 
O 1-MCP reduziu a taxa respiratória dos frutos (Figura 4). Ao final do armazenamento, os frutos tratados com a concentração de 900 nL.L $\mathrm{L}^{-1}$ apresentaram baixa taxa respiratória $\left(42,5 \mathrm{mgCO} 2 \cdot \mathrm{kg}^{-1} \cdot \mathrm{h}^{-1}\right)$ em relação aos frutos tratados nas concentrações de 100 nL. . $\mathrm{L}^{-1} \quad\left(67,5 \mathrm{mgCO} 2 \cdot \mathrm{kg}^{-1} \cdot \mathrm{h}^{-1}\right)$ e $300 \quad \mathrm{~nL} \cdot \mathrm{L}^{-1} \quad\left(59,8 \mathrm{mgCO} 2 \cdot \mathrm{kg}^{-1} \cdot \mathrm{h}^{-1}\right)$ que apresentaram valores similares entre si, mas bastante inferiores aos frutos não tratados $\left(82,1 \mathrm{mgCO}_{2} \cdot \mathrm{kg}^{-1} \cdot \mathrm{h}^{-1}\right)$.

O 1-MCP é caracterizado por ser um competidor pelo sítio de ligação do etileno na célula. Quando aplicado no momento correto, o 1-MCP ocupa os sítios de ligação do etileno e impede os seus efeitos, como por exemplo a síntese de enzimas degradativas, aumento na taxa respiratória e a própria produção de etileno. A capacidade de conservação de um produto agrícola está inversamente relacionada à taxa respiratória, e em muitos casos, com a taxa de produção de etileno (Kader, 1994). A redução na taxa respiratória dos frutos tratados com 1-MCP também foi verificada em trabalhos anteriores (Abdi et al., 1998; Golding et al., 1998; Fan et al., 1999; Jacomino et al., 2002).

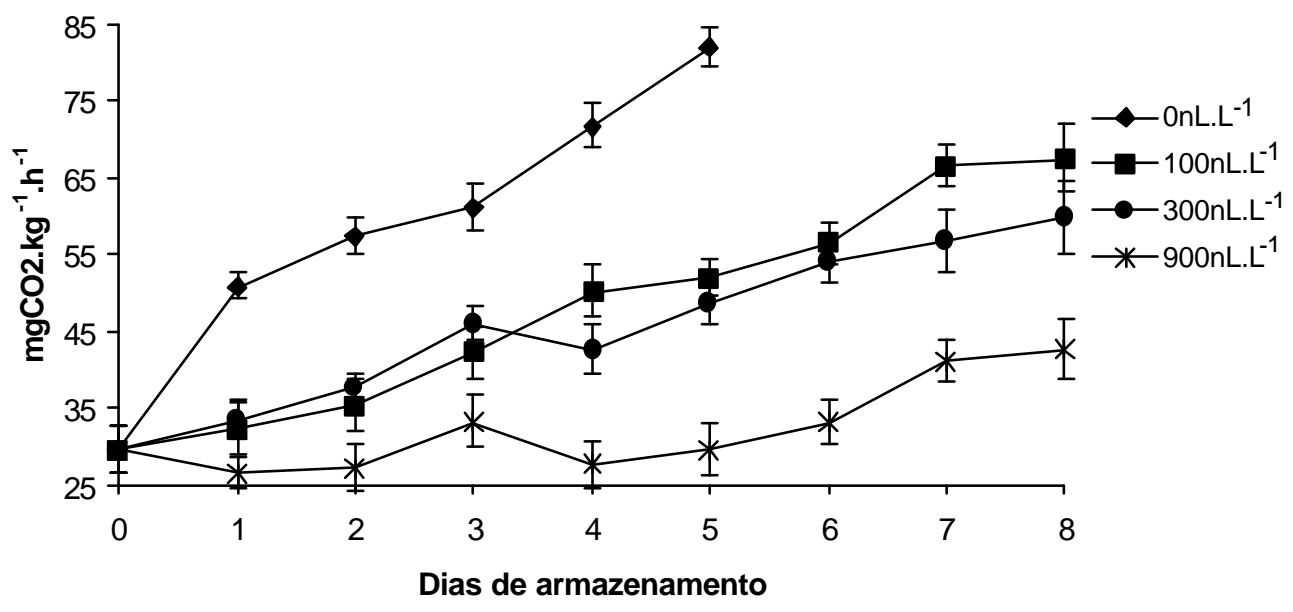

Figura 4 - Taxa respiratória de goiabas 'Pedro Sato' tratadas com 1-MCP e armazenadas a $25^{\circ} \mathrm{C}$ 
No presente experimento foi verificado que a eficiência do 1-MCP está diretamente ligada com a relação concentração x tempo de exposição.

As concentrações de 100 e $300 \mathrm{~nL} \cdot \mathrm{L}^{-1}$ de 1 -MCP associadas ao tempo de exposição de 3 horas apresentaram baixa eficiência em retardar o amadurecimento dos frutos, prolongando o período de armazenamento por apenas 1 dia em relação aos frutos não tratados, porém quando os frutos foram expostos durante 6 ou 12 horas, essas concentrações prolongaram o armazenamento por 2 a 4 dias. As frutas tratadas com 300 nL.L ${ }^{-1}$ de 1-MCP durante 6 ou 12 horas apresentaram resposta similar às frutas tratadas com 900 nL.L ${ }^{-1}$ de 1-MCP durante 3horas.

A aplicação de 900 nL.L ${ }^{-1}$ de 1-MCP durante 6 ou 12 horas, foi considerada demasiadamente alta por não permitir o posterior amadurecimento dos frutos.

\subsection{Conclusões}

$\checkmark$ O 1-MCP foi eficiente em retardar o amadurecimento de goiabas 'Pedro Sato' mantidas sob condição ambiente.

$\checkmark$ A eficiência do tratamento com 1-MCP depende da relação concentração $\mathrm{x}$ tempo de exposição. À medida que se aumenta a concentração, pode-se diminuir o tempo de exposição obtendo-se o mesmo efeito.

$\checkmark$ A concentração de 300 nL.L $\mathrm{L}^{-1}$ de 1-MCP durante 6 e 12 h, e a concentração de 900 nL.L $\mathrm{L}^{-1}$ durante 3 horas, permitiram a conservação de goiabas por 9 dias.

$\checkmark$ A concentração de 900 nL.L $\mathrm{L}^{-1}$ de 1 -MCP durante 6 ou 12 horas, não é recomendada para goiaba por não permitir o posterior amadurecimento dos frutos. 


\section{CONSERVAÇÃO DE GOIABAS 'PEDRO SATO' TRATADAS COM 1-METILCICLOPROPENO DURANTE 3 HORAS E ARMAZENADAS SOB CONDIÇÃO AMBIENTE E SOB REFRIGERAÇÃO}

\section{Resumo}

Goiabas 'Pedro Sato' foram tratadas com 0, 100, 300 e 900 nL.L'1 de 1metilciclopropeno durante 3 horas e armazenadas a $25^{\circ} \mathrm{C}$ e a $10^{\circ} \mathrm{C}$. As variáveis foram analisadas aos 2, 4, 6 e 8 dias de armazenamento para os frutos armazenados sob condição ambiente e aos 4, 8, 12 e 16 dias de armazenamento para os frutos armazenados sob refrigeração. Foram analisadas as seguintes variáveis: coloração da casca, coloração da polpa, perda de massa, firmeza da polpa, acidez total titulável (ATT), teor de ácido ascórbico, teor de sólidos solúveis totais (SST), incidência de podridões e respiração. A aplicação de $900 \mathrm{~nL}^{-\mathrm{L}^{-1}}$ de 1 -MCP durante 3 horas foi eficiente em retardar a coloração da casca e a firmeza dos frutos nas duas temperaturas de armazenamento. A concentração de 300 nL.L $\mathrm{L}^{-1}$ de 1-MCP apenas mostrou-se eficiente em retardar a coloração da casca quando os frutos foram armazenados a $10^{\circ} \mathrm{C}$. $\mathrm{O}$ efeito do 1-MCP foi bastante significativo em diminuir a incidência das podridões nas duas temperaturas de armazenamento. Os frutos armazenados a $25^{\circ} \mathrm{C}$ apresentaram menor teor de sólidos solúveis nos frutos tratados com 300 e 900 nL.L $\mathrm{L}^{-1}$ de 1-MCP. No armazenamento a $25^{\circ} \mathrm{C}$, o teor de ácido cítrico foi maior nos frutos tratados com 900 $n L . L^{-1}$ de 1-MCP, enquanto que no armazenamento a $10^{\circ} \mathrm{C}$ não houve diferença entre os frutos tratados que obtiveram um maior teor que os frutos não tratados. Para os frutos 
armazenados a $10^{\circ} \mathrm{C}$, não houve influência do $1-\mathrm{MCP}$ nas variáveis coloração da polpa e teor de sólidos solúveis totais. A taxa respiratória foi menor nos frutos tratados com 300 e $900 \mathrm{~nL} . \mathrm{L}^{-1}$ de 1-MCP durante o armazenamento a $25^{\circ} \mathrm{C}$. Para os frutos armazenados a $10^{\circ} \mathrm{C}$ a taxa respiratória manteve-se praticamente constante. $\mathrm{O}$ 1-MCP foi eficiente em retardar o amadurecimento dos frutos em condição ambiente e sob refrigeração.

Palavras-chave: Psidium guajava, 1-metilciclopropeno, temperatura, pós-colheita.

\section{POSTHARVEST CONSERVATION OF 'PEDRO SATO’ GUAVAS TREATED WITH 1-METHYLCICLOPROPENE FOR 3 HOURS AND STORED AT ROOM TEMPERATURE AND REFRIGERATION}

\section{Summary}

'Pedro Sato' guava fruits were treated with 0, 100, 300 and 900nL.L ${ }^{-1}$ of 1methylcyclopropene (1-MCP) for 3 hours and stored at $25^{\circ} \mathrm{C}$ and $10^{\circ} \mathrm{C}$. Fruits characteristics were evaluated at 2, 4, 6 and 8 days of storage for fruits stored at $25^{\circ} \mathrm{C}$ and 4, 8, 12 and 16 days of storage for fruits stored under refrigeration condition. Skin color, pulp color, weight loss, firmness, total titrable acidity, ascorbic acid, total soluble solids, decay incidence and respiration rate were evaluated. The application of $900 \mathrm{~nL} . \mathrm{L}^{-}$ 1 of 1-MCP for 3 hours was efficient on delaying the skin color and firmness of the fruits for both temperatures of storage. The concentration of $300 \mathrm{~nL} . \mathrm{L}^{-1}$ of $1-\mathrm{MCP}$ was efficient on delaying the skin color when fruits were stored at $10^{\circ} \mathrm{C}$. The $1-\mathrm{MCP}$ treatment was significant by efficient on reducing the decay incidence in both storage temperature conditions. Fruits treated with 300 and 900 nL.L ${ }^{-1}$ of $1-\mathrm{MCP}$ and stored at $25^{\circ} \mathrm{C}$ showed smaller soluble solids content. For storage at $25^{\circ} \mathrm{C}$ temperature condition, the citric acid was higher in the fruits treated with $900 \mathrm{~nL} . \mathrm{L}^{-1}$ of $1-\mathrm{MCP}$, while in the storage at $10^{\circ} \mathrm{C}$ there was not any difference between treated fruits even though they showed higher citric acids content than control. On fruits stored at $10^{\circ} \mathrm{C}$ temperature 
condition, there was no influence of the 1-MCP on fruit pulp color and on the total soluble solids. The respiration rate was lower in treated fruits with 300 and $900 \mathrm{~nL} . \mathrm{L}^{-1}$ of $1-\mathrm{MCP}$ during the storage at $25^{\circ} \mathrm{C}$. For the fruits stored at $10^{\circ} \mathrm{C}$ the respiration rate stayed practically constant. The 1-MCP was efficient on delaying fruits ripening at room temperature and under refrigerated condition.

Key-words: Psidium guajava, 1-methylcyclopropene, temperature, postharvest

\subsection{Introdução}

A goiabeira (Psidium guajava L.) encontra-se atualmente muito difundida por todas as regiões tropicais e subtropicais do mundo. A goiaba destaca-se por apresentar elevado valor nutritivo e excelentes características organolépticas, tornando-a muito adequada para o consumo in natura (Carvalho, 1994).

Atualmente, o Brasil é o maior produtor mundial de goiabas (260 mil toneladas anuais) e os pomares se acham concentrados nos estados de São Paulo e Pernambuco, onde respondem por mais de $80 \%$ da produção nacional (Agrianual, 2000).

A participação no mercado internacional da goiaba in natura é inexpressiva. Segundo Choudhury, et al. (2001), alguns fatores são responsáveis por esse problema, entre os quais destaca-se o pouco conhecimento do produto por parte dos consumidores dos mercados importadores e o alto grau de perecibilidade do fruto na fase pós-colheita. Este último fator exige que o produto seja bem acondicionado e escoado para o mercado internacional via aérea, o que onera demasiadamente os custos de comercialização. Sendo assim, o mercado de goiaba continua acentuadamente dependente do mercado nacional.

As goiabas são frutos altamente perecíveis e possuem uma atividade metabólica intensa. Quando mantida à temperatura ambiente, atingem o amadurecimento completo entre 3 e 5 dias (Gongatti Netto et al., 1996). Devida essa alta perecibilidade, o controle do amadurecimento é fundamental para o aumento na vida útil após a colheita. Os principais fatores que depreciam a qualidade pós-colheita da goiaba são a rápida perda da coloração verde da casca, amolecimento excessivo, elevada incidência de podridões, murchamento dos frutos e perda de brilho (Jacomino, 1999). 
A recente descoberta de que o gás 1-metilciclopropeno (1-MCP) interfere na ligação do etileno ao seu sítio receptor, representa uma nova e potente ferramenta para o manejo pós-colheita de futos climatéricos (Sisler e Serek, 1997). Tem sido demonstrado que este inibidor da ação do etileno retarda a maturação e senescência de várias espécies de frutos, tais como goiaba (Kluge et al., 2000), maçã (Rupasinghe et al., 2000; Watkins et al., 2000; Fan et al., 1999), banana (Harris et al., 2000; Sisler \& Serek, 1997; Golding et al., 1998; e Jiang et al., 1999a e 1999b), ameixa (Abdi et al., 1998), damasco (Fan et al., 2000), abacate (Feng et al., 2000), tomate (Nakatsuka et al., 1997; Sisler \& Serek, 1997), brocoli (Fan et al., 2000; Ku \& Wills, 1999) e morango (Ku \& Wills, 1999).

$\mathrm{O}$ armazenamento em baixas temperaturas tem sido considerado o método mais eficiente para manter as qualidades da maioria dos produtos hortifrutícolas, devido aos seus efeitos de redução nos processos de respiração, transpiração, produção de etileno, amadurecimento, senescência e desenvolvimento de podridões (Handerburg et al., 1986). Invariavelmente, o abaixamento da temperatura aumenta o período de conservação. Em frutos climatéricos, como a maioria das variedades de goiaba, a redução da temperatura retarda o pico climatérico e, por consequiência, o seu amadurecimento (Kader, 1992).

O objetivo deste experimento foi avaliar os efeitos de concentrações de 1-MCP durante 3 horas em goiabas armazenadas sob condição ambiente e refrigeração.

\subsection{Material e Métodos}

Goiabas 'Pedro Sato' foram colhidas em pomar comercial localizado no município de Vista Alegre do Alto (SP), em agosto de 2002 e transportadas ao Laboratório de Pós-colheita de Produtos Hortícolas do Departamento de Produção Vegetal da ESALQ/USP, em Piracicaba (SP). Foram utilizados frutos sem defeitos, em estádio de maturação caracterizado pela mudança da cor da casca de verde-escuro para verde-claro, com massa de $165 \pm 10 \mathrm{~g}$. 
Este experimento foi subdividido em dois experimentos: experimento 1, onde foi verificado o efeito do 1-MCP em temperatura ambiente e experimento 2, onde foi verificado o efeito do 1-MCP sob refrigeração.

Os frutos foram selecionados e submetidos aos tratamentos com Smartfresh ${ }^{\circledR}$, na formulação pó molhável, contendo $0,14 \%$ de i.a. 1-MCP. Foram utilizadas as seguintes concentrações de 1-MCP: 0, 100, 300 e 900 nL.L $\mathrm{L}^{-1}$. A aplicação constou da colocação dos frutos em câmara hermética e exposição ao produto por período de $3 \mathrm{~h}$ a $24-25^{\circ} \mathrm{C}$ e a $10^{\circ} \mathrm{C}$.

Para produzir as concentrações desejadas de 1-MCP no interior das câmaras, quantidade pré-determinada de Smartfresh $^{\circledR}$, na forma de pó, foram colocadas em frascos com tampas $\left(0,16 \mathrm{~g}\right.$ de $\operatorname{Smartfresh}^{\circledR}$ representam $100 \mathrm{~nL} \cdot \mathrm{L}^{-1}$ de 1 -MCP em $\left.1 \mathrm{~m}^{3}\right)$. Adicionou-se $20 \mathrm{ml}$ de água destilada a $50^{\circ} \mathrm{C}$ em cada frasco e agitourse os mesmos até a completa dissolução do produto. Os frascos foram abertos no interior das câmaras, as quais foram fechadas imediatamente para evitar a perda do gás. Após os tratamentos, as câmaras foram abertas e os frutos foram colocados em condição ambiente $\left(25^{\circ} \mathrm{C}\right)$ e sob refrigeração $\left(10^{\circ} \mathrm{C}\right)$.

O delineamento experimental adotado foi inteiramente casualizado, em esquema fatorial. Os fatores estudados foram concentração de 1-MCP e tempo de exposição ao produto. Foram utilizadas quatro repetições por tratamento com quatro frutos por parcela, para cada experimento, totalizando 512 frutos.

Os resultados das análises foram submetidos a análise do desvio padrão. As diferenças entre dois tratamentos maior que a soma de dois desvios padrões foram consideradas significativas.

As variáveis analisadas foram: a) Coloração da casca e da polpa: determinada com colorímetro Minolta Croma Meter CR-300, e os resultados expressos em ângulo de cor $\left({ }^{\circ} \mathrm{h}\right)$ para cor da casca e croma para cor da polpa. $\mathrm{O}$ h define a coloração básica, onde $0^{\circ}=$ vermelho, $90^{\circ}=$ amarelo e $180^{\circ}=$ verde. $\mathrm{O}$ croma define a saturação e intensidade da cor definida pelo $\mathrm{h}^{\mathrm{o}}$ (McGuire, 1992). Para cor da casca, realizaram-se duas leituras em lados opostos da região equatorial e para cor da polpa, uma leitura no centro da região placentária, após corte transversal; b) Perda de massa: por diferença, em 
$\%$, entre a massa inicial e final da repetição; c) Firmeza da polpa: determinada com penetrômetro digital, ponteira $8 \mathrm{~mm}$, tomando-se duas leituras por fruta, em lados opostos da região equatorial e os resultados expressos em Newton; d)Acidez total titulável (ATT): determinada por titulometria de acordo com metodologia de Carvalho et al. (1990) e os resultados expressos em \% de ácido cítrico; e)Teor de ácido ascórbico: determinado por titulometria de acordo com metodologia descrita por Carvalho et al. (1990), sendo os resultados expressos em mg de ácido ascórbico por 100g de polpa; f)Teor de sólidos solúveis totais (SST): determinada através de leitura direta em refratômetro digital Atago modelo Palete 101, utilizando-se uma amostra centrifugada da fruta, expressando os resultados em ${ }^{\circ}$ Brix; g)Incidência de podridões: avaliada pela contagem do número de frutos afetados, sendo os resultados expressos em porcentagem e h) Taxa respiratória: para esta determinação, amostras de frutos com massa e volume conhecidos foram incubadas em frascos herméticos, com volume conhecido. Após uma hora determinou-se a concentração de $\mathrm{CO}_{2}$ no interior dos frascos utilizando-se de um analisador de gases PBI Dansensor modelo Check Mate. A taxa respiratória foi calculada e expressa em $\mathrm{mgCO} \cdot \mathrm{kg}^{-1} \cdot \mathrm{h}^{-1}$. Utilizaram-se 5 repetições para cada tratamento.

Para o experimento 1, a taxa respiratória foi analisada diariamente e as demais

características foram avaliadas aos 2, 4, 6 e 8 dias de armazenamento. Para o experimento 2, a taxa respiratória foi analisada a cada 2 dias e as demais variáveis foram analisadas aos 4, 8, 12 e 16 dias de armazenamento.

Os resultados obtidos foram submetidos à analise de variância (teste F) e, em caso de significância, as médias foram comparadas pelo teste de Tukey ao nível de 5\% de probabilidade.

\subsection{Resultados e Discussão}

\section{Experimento 1 - Frutos armazenados a $25^{\circ} \mathrm{C}$}

Os frutos tratados com 1-MCP e armazenados a $25^{\circ} \mathrm{C}$ apresentaram perda da coloração verde da casca mais lenta do que os frutos não tratados (Figura 1 e Figura 2). No $4^{\circ}$ dia de armazenamento, os frutos não tratados apresentaram cor da casca amarela, 
ou seja, estavam no limite de comercialização, enquanto os frutos dos demais tratamentos mantinham a cor da casca verde-amarela. A partir do $4^{\circ}$ dia de armazenamento, houve um rápido decréscimo na retenção da cor da casca dos frutos tratados com 100 e 300 nL.L ${ }^{-1}$ de 1-MCP. Provavelmente, novos sítios receptores de etileno foram sintetizados, permitindo a ligação do etileno à molécula receptora e resultando no amadurecimento desses frutos. Os frutos tratados com 900nL.L ${ }^{-1}$ de 1-MCP foram os que apresentaram melhor retenção da coloração da casca. No $8^{\circ}$ dia de armazenamento, esses frutos ainda não se encontravam totalmente amarelos.

A perda da cor verde da casca é devida à quebra da estrutura da molécula de clorofila, envolvendo a atividade da enzima clorofilase. O aumento da atividade desta enzima está geralmente associada com a produção de etileno durante o amadurecimento do fruto (Tucker, 1993). O 1-MCP se liga ao sítio de ligação do etileno na célula evitando a ação do mesmo sobre os processos fisiológicos de amadurecimento (Serek et al., 1995). Assim a perda da cor verde, resultante do processo normal de amadurecimento, foi retardada com a aplicação do 1-MCP. A retenção do desenvolvimento da coloração da casca em frutos tratados com 1-MCP também foi verificada em ameixa (Abdi et al., 1998), banana (Golding et al., 1998), tomate (Dupille \& Sisler, 1995), abacate (Fan et al, 2000) e mamão (Jacomino et al., 2002).

A polpa dos frutos, na região placentária, apresentava-se cor-de-rosa quando estes foram colhidos (croma $=34,5)$ e tornou-se vermelha intensa após o amadurecimento (croma $=41,5$ a 43,0). O croma indica a variação na intensidade das cores, sendo maior, quanto mais vívida a cor. A coloração da polpa dos frutos foi afetada pela aplicação de 1-MCP, onde os frutos tratados com 300 e 900 nL.L L $^{-1}$ de 1-MCP apresentaram menor intensidade na coloração da polpa até o $4^{\circ}$ dia de armazenamento. A partir do $6^{\circ}$ dia de armazenamento, os frutos apresentaram pouca diferença na retenção da intensidade da cor. Provavelmente, a partir do $6^{\circ}$ dia de armazenamento houve síntese de novos receptores de etileno na polpa promovendo o amadurecimento do fruto e com isso o croma tornou-se mais vívido (Figura 2).

O 1-MCP afetou a porcentagem de frutos com podridões ao longo do período de armazenamento (Tabela 1). O fungo mais frequientemente encontrado foi Colletotrichum 
gloeosporioides. A incidência de podridão foi menor nos frutos que demoraram mais para amadurecer. Os frutos não tratados apresentaram alta porcentagem de podridão a partir do $4^{\circ}$ dia de armazenamento. Nos frutos tratados com 100 ou 300nL.L ${ }^{-1}$ de $1-\mathrm{MCP}$, altas porcentagens de podridões foram observadas a partir do $6^{\circ}$ dia de armazenamento. Os frutos tratados com $900 \mathrm{~nL} . \mathrm{L}^{-1}$ apresentaram alta porcentagem de podridão no $8^{\circ}$ dia de armazenamento. Em goiaba, as podridões pós-colheita aumentam conforme o amadurecimento avança (Jacomino, 1999).

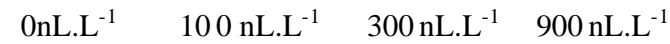

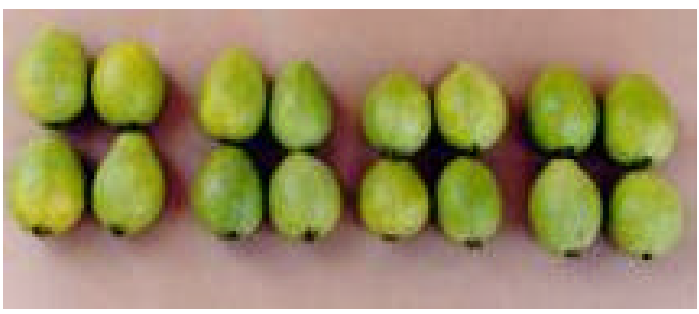

$2^{\circ}$ dia de armazenamento

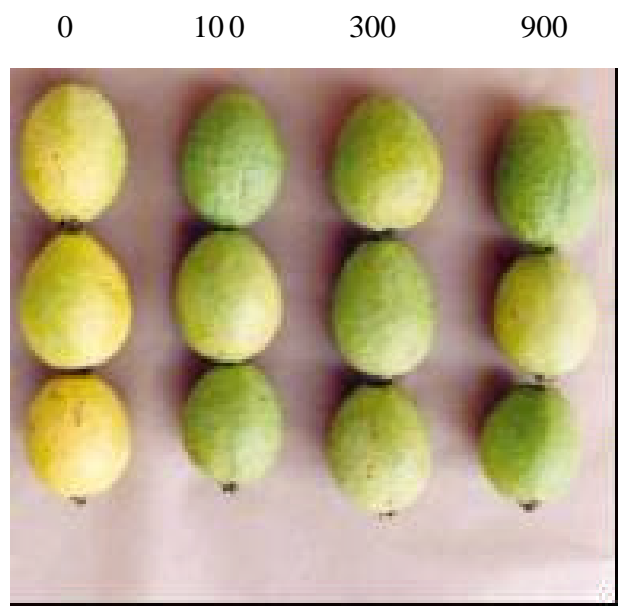

$4^{\circ}$ dia de armazenamento

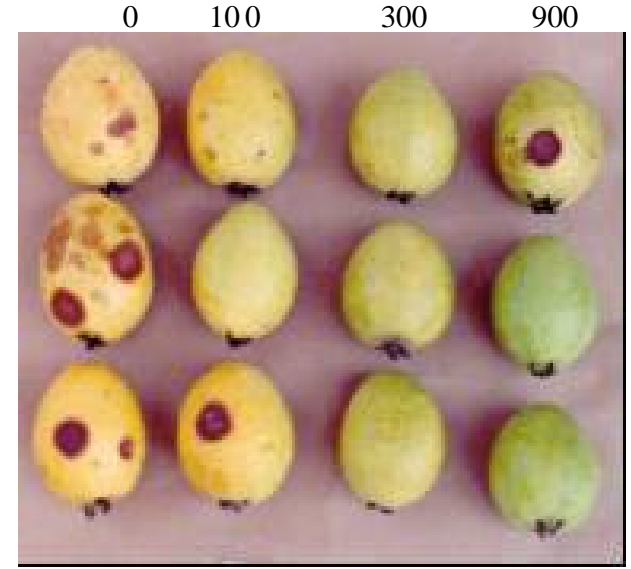

$6^{\circ}$ dia de armazenamento

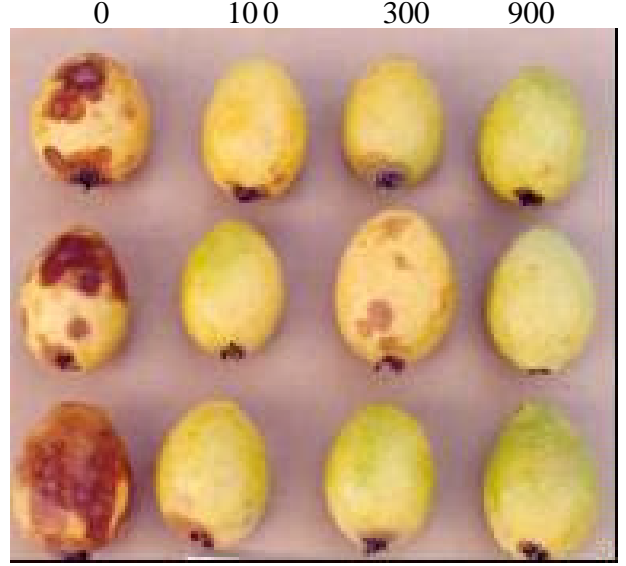

$8^{\circ}$ dia de armazenamento

Figura 1 - Goiabas 'Pedro Sato' tratadas com 1-MCP durante 3 horas e armazenadas a $25^{\circ} \mathrm{C}$. 
Tabela 1. Efeito do 1-MCP na incidência de podridão em goiabas 'Pedro Sato' tratadas com 1-MCP durante $3 \mathrm{~h}$ e armazenadas a $25^{\circ} \mathrm{C}$.

\begin{tabular}{lcccc}
\hline $\begin{array}{c}\text { Concentração } \\
\text { de 1-MCP }\end{array}$ & $\mathbf{2}$ & \multicolumn{3}{c}{ Dias de armazenamento } \\
\hline & & $\mathbf{4}$ & $\mathbf{6}$ & $\mathbf{8}$ \\
\hline nL.L & & & & \\
$100 \mathrm{~nL} . \mathrm{L}^{-1}$ & 0 & 31 & 63 & 100 \\
$300 \mathrm{~nL} \cdot \mathrm{L}^{-1}$ & 0 & 13 & 38 & 100 \\
$900 \mathrm{~nL} \cdot \mathrm{L}^{-1}$ & 0 & 6 & 31 & 81 \\
\hline
\end{tabular}

A firmeza da polpa dos frutos recém-colhidos foi de 78,7N e após o $6^{\circ}$ dia de armazenamento variou entre 11,0 a $22,8 \mathrm{~N}$. O 1-MCP, independente da concentração utilizada, foi eficaz em manter a firmeza dos frutos até o $4^{\circ}$ dia de armazenamento (Figura 2).

A concentração de 900 nL. $\mathrm{L}^{-1}$ de 1 -MCP proporcionou maior manutenção da firmeza da polpa dos frutos durante os períodos de avaliação, mantendo-os firmes até o $6^{\circ}$ dia de armazenamento. Os frutos tratados com 100 e $300 \mathrm{~nL} . \mathrm{L}^{-1}$ de $1-\mathrm{MCP}$ apresentaram boa retenção da firmeza até o $4^{\circ}$ dia de armazenamento. Os frutos não tratados apresentaram elevada perda de firmeza logo no $2^{\circ}$ dia de armazenamento. A firmeza de polpa do fruto é determinada pela força de coesão entre as pectinas. Com a evolução do amadurecimento ocorre atuação de enzimas pectinolíticas, que transformam a pectina insolúvel em solúvel e promovem o amolecimento dos frutos. $\mathrm{O}$ amadurecimento dos frutos é um dos processos do amadurecimento mais sensíveis ao etileno (Lelièvre et al., 1997). A maior firmeza dos frutos tratados com 900 nL.L ${ }^{-1}$ de $1-$ MCP está provavelmente associada à redução da atividade das enzimas pectinolíticas, induzida pela menor ação do etileno. Resultados similares a estes foram encontrados em maçã (Fan et al., 1999), banana (Jiang et al., 1999) e mamão (Jacomino et al., 2002).

O teor de sólidos solúveis foi menor nos frutos tratados com 300 e 900 nL.L ${ }^{-1}$ de 1-MCP no decorrer do armazenamento, devido o 1-MCP nessas concentrações retardar o 
amadurecimento dos frutos (Figura 2). O teor de açúcares usualmente aumenta com o amadurecimento dos frutos através de processos de biossíntese ou pela degradação de polissacarídeos (Chitarra \& Chitarra, 1990). O menor teor de sólidos solúveis em frutos tratados com 1-MCP foi verificada em trabalhos anteriores (Watkins et al., 2000; Botrel, 2002).

O teor de ácidos orgânicos diminui durante o amadurecimento, por serem substratos da respiração em resposta à maior exigência metabólica (Wills et al., 1981). De maneira geral, houve decréscimo do teor de ácido cítrico durante o armazenamento, sendo este comportamento mais evidente nos frutos que não receberam 1-MCP. Nos frutos tratados, a retenção da acidez foi maior quanto maior a concentração de 1-MCP aplicada (Figura 2).

O teor de ácido ascórbico não foi influenciado pelo 1-MCP. Observou-se uma tendência maior de retenção de ácido ascórbico da maior para a menor concentração de 1-MCP. O teor de ácido ascórbico variou de 50 a 53 mg de ácido ascórbico/100g de polpa durante o armazenamento (Figura 2).

Apenas os frutos tratados com 900 nL.L $\mathrm{L}^{-1}$ de 1-MCP apresentaram considerável redução na taxa respiratória durante o armazenamento (Figura 3), enquanto os frutos dos demais tratamentos mostraram comportamento respiratório semelhante entre si. O 1MCP é caracterizado por ser um competidor pelo sítio de ligação do etileno na célula. Quando aplicado no momento correto, o 1-MCP ocupa os sítios de ligação do etileno e impede os seus efeitos, como por exemplo a síntese de enzimas degradativas, aumento na taxa respiratória e a própria produção de etileno. A capacidade de conservação de um produto agrícola está inversamente relacionada à taxa respiratória, e em muitos casos, com a taxa de produção de etileno (Kader, 1994). A redução na taxa respiratória explica a maior conservação dos frutos tratados com 900 nL.L ${ }^{-1}$ de 1-MCP. A menor taxa respiratória de frutos tratados com 1-MCP também foi verificada em trabalhos anteriores (Abdi et al., 1998; Golding et al., 1998; Fan et al., 1999; Jiang et al., 1999; Jacomino et al., 1999). 

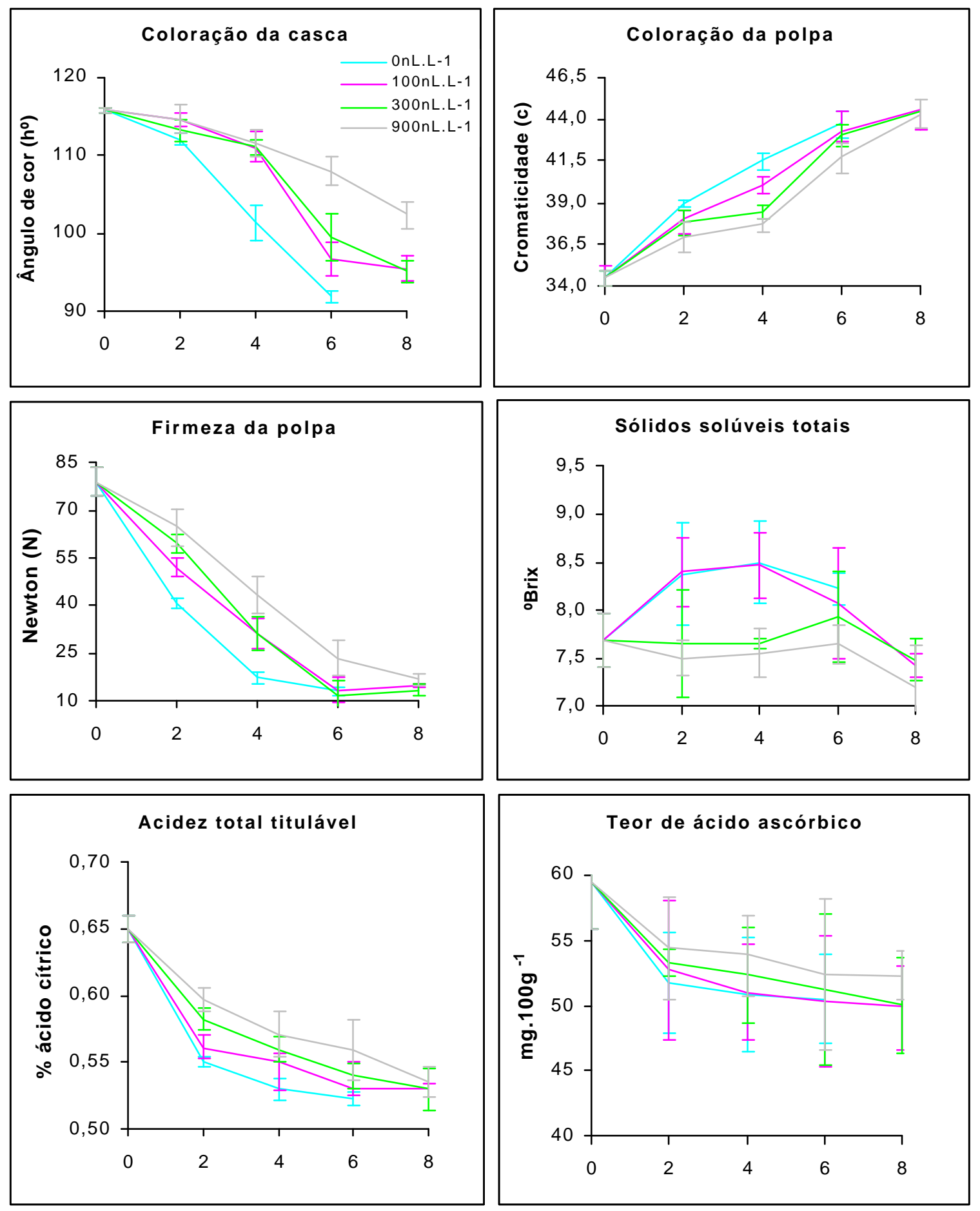

Figura 2 - Coloração da casca, coloração da polpa, firmeza da polpa, sólidos solúveis totais, acidez total titulável e teor de ácido ascórbico de goiabas 'Pedro Sato' tratadas com 1-MCP durante $3 \mathrm{~h}$ e armazenadas a $25^{\circ} \mathrm{C}$. 


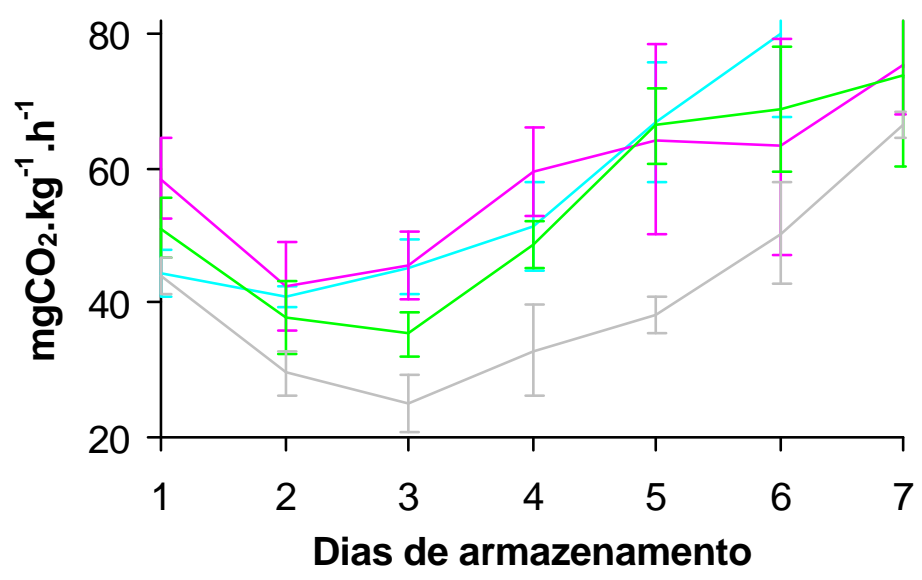

Figura 3 - Taxa respiratória de goiabas 'Pedro Sato' tratadas com 1-MCP durante 3 h e armazenadas a $25^{\circ} \mathrm{C}$.

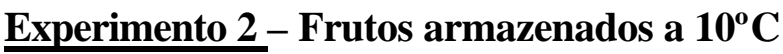

Os frutos apresentaram pequena redução da cor verde da casca enquanto estavam armazenados a $10^{\circ} \mathrm{C}$ (Figura 4a). Entretanto, após transferência para a condição ambiente $\left(25^{\circ} \mathrm{C}\right)$, pôde-se observar que as concentrações de 300 e $900 \mathrm{~nL} . \mathrm{L}^{-1}$ proporcionaram melhor retenção da cor da casca, o que pode ser observado pelo ângulo de cor $\left(h^{\circ}\right)$ (Figura $4 b$ e Figura 5). As goiabas foram armazenadas com $h^{\circ}=115,8$ (verde-claro). Os frutos não tratados e os tratados com 100nL.L $\mathrm{L}^{-1}$ de 1-MCP atingiram valores de $\mathrm{h}^{\mathrm{o}}$ de 96,6 e 97,5 (amarelo), respectivamente. Os frutos tratados com 300 e 900nL.L $\mathrm{L}^{-1}$ de 1-MCP atingiram valores de $\mathrm{h}^{\mathrm{o}}$ de 103,2 e 107,3, respectivamente, ao final do armazenamento (verde-amarelo).

$\mathrm{O}$ armazenamento em baixas temperaturas reduz as atividades enzimáticas (Hardenburg et al., 1986). A cada aumento de $10^{\circ} \mathrm{C}$ na temperatura aumenta-se de 2 a 3 vezes a taxa das reações químicas e bioquímicas (Chitarra \& Chitarra, 1990), aumentando a atividade enzimática. Assim a perda da cor verde, resultante do processo normal de amadurecimento, foi retardada com o armazenamento refrigerado e com a aplicação do 1-MCP. A retenção do desenvolvimento da coloração da casca em frutos 
tratados com 1-MCP e armazenados em ambiente refrigerado também foi verificada em pêra (Fan et al, 2002).

Observa-se que no armazenamento refrigerado a aplicação de 300 nL.L ${ }^{-1}$ de $1-$ MCP foi eficiente em retardar a perda da cor verde da casca, enquanto que a aplicação dessa mesma concentração sob condição ambiente (Experimento 1) apresentou efeito similar aos frutos não tratados, não sendo eficiente em reter a coloração verde da casca. Provavelmente, isso se deve a combinação do efeito do 1-MCP com o efeito da refrigeração.
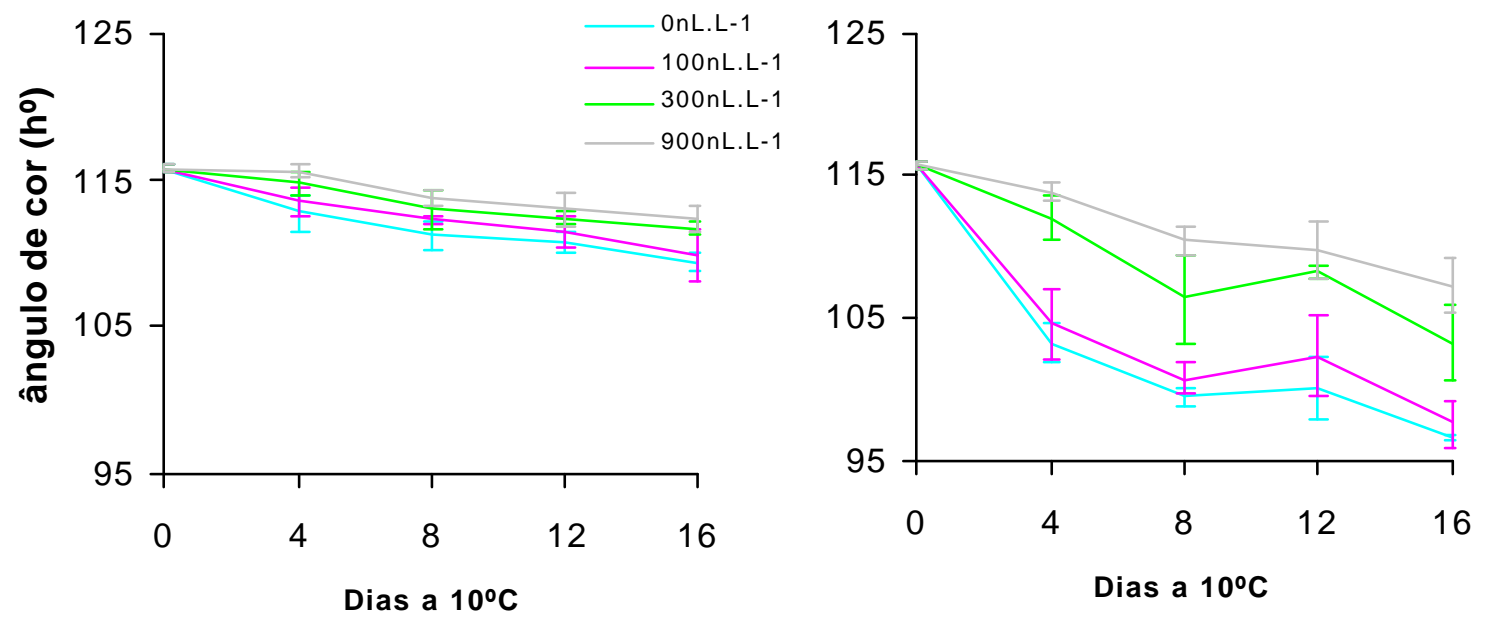

Figura 4 - Coloração da casca de goiabas 'Pedro Sato' tratadas com 1-MCP durante 3 horas e armazenadas a $10^{\circ} \mathrm{C}$. (a) frutos armazenados a $10^{\circ} \mathrm{C}$ e (b) frutos armazenados a $10^{\circ} \mathrm{C}+2$ dias a $25^{\circ} \mathrm{C}$.

A retenção do amadurecimento causada pelo armazenamento refrigerado e pelo 1-MCP refletiu-se sobre o percentual de frutos afetados por podridões (Tabela 2). No presente experimento foi verificado incidência de fungos do gênero Colletotrichum gloeosporioides. $\mathrm{O}$ armazenamento refrigerado associado ao 1-MCP foi eficiente, em reter $\mathrm{o}$ desenvolvimento de podridões. Os frutos que permaneceram a $10^{\circ} \mathrm{C}$, apresentaram baixa incidência de podridão. Somente no tratamento sem 1-MCP, 
encontrou-se algum fruto podre no $16^{\circ}$ dia de armazenamento (incidência $<15 \%$ ). Quando os frutos foram colocados por 2 dias a $25^{\circ} \mathrm{C}$, o percentual de podridões foi baixo até o $12^{\circ}$ dia de armazenamento $(<20 \%)$ para os frutos tratados com $1 \mathrm{MCP}$, enquanto que os frutos não tratados apresentavam 63\%. Jacomino et al. (2002), também verificaram menor incidência de podridões em mamões tratados com 1-MCP.

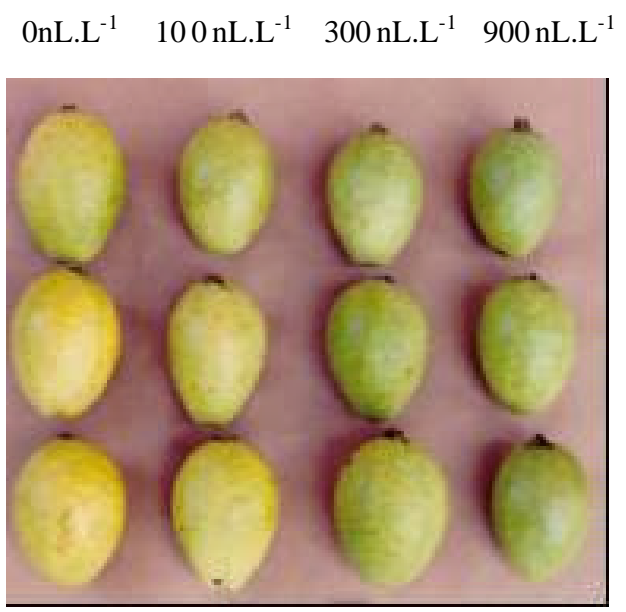

4 dias a $10^{\circ} \mathrm{C}+2 \mathrm{~d}$ a $25^{\circ} \mathrm{C}$

$0 \quad 100$

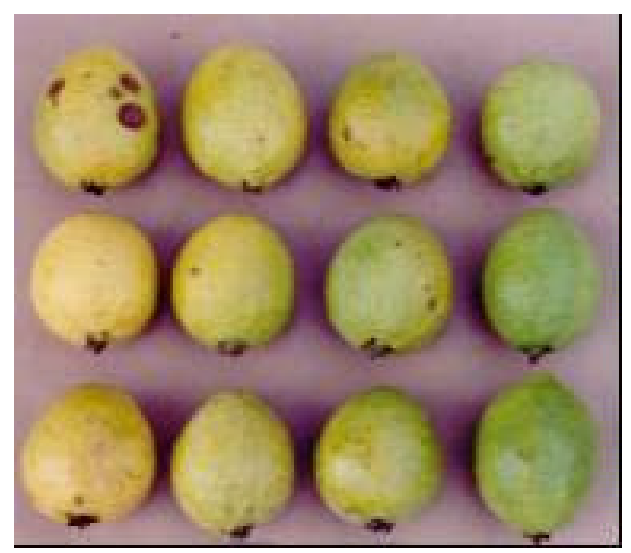

12 dias a $10^{\circ} \mathrm{C}+2 \mathrm{~d}$ a $25^{\circ} \mathrm{C}$

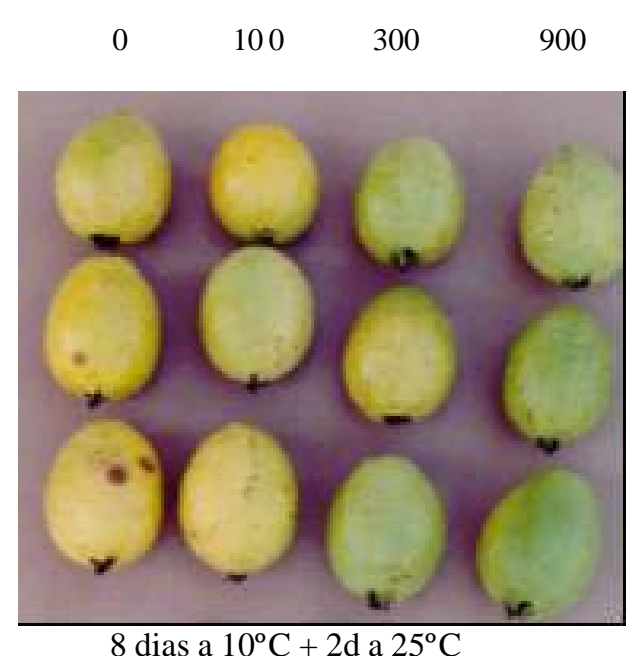

8 dias a $10^{\circ} \mathrm{C}+2 \mathrm{~d}$ a $25^{\circ} \mathrm{C}$

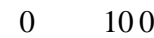

300

900

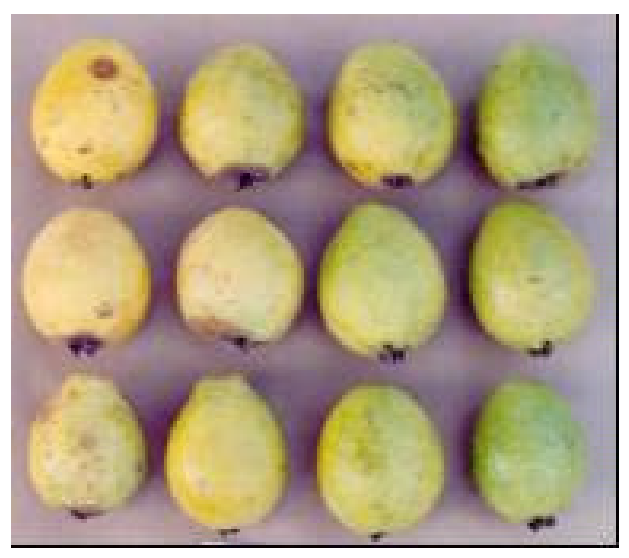

16 dias a $10^{\circ} \mathrm{C}+2 \mathrm{~d}$ a $25^{\circ} \mathrm{C}$

Figura 5 - Coloração da casca de goiabas 'Pedro Sato' tratadas com 1-MCP durante 3 horas e armazenadas a $10^{\circ} \mathrm{C}+2$ dias a $25^{\circ} \mathrm{C}$. 
Tabela 2. Efeito do 1-MCP na incidência de podridão em goiabas 'Pedro Sato' armazenadas a $10^{\circ} \mathrm{C}$ mais 2 dias a $25^{\circ} \mathrm{C}$.

\begin{tabular}{|c|c|c|c|c|}
\hline \multirow{2}{*}{$\begin{array}{l}\text { Concentração } \\
\text { de 1-MCP }\end{array}$} & \multicolumn{4}{|c|}{ Dias de armazenamento a $10^{\circ} \mathrm{C}$} \\
\hline & 4 & 8 & 12 & 16 \\
\hline & \multicolumn{4}{|c|}{-- } \\
\hline 0 nL.L $\mathrm{L}^{-1}$ & 0 & 44 & 63 & 81 \\
\hline 100 nL.L ${ }^{-1}$ & 0 & 13 & 19 & 38 \\
\hline 300 nL.L ${ }^{-1}$ & 0 & 6 & 13 & 31 \\
\hline 900 nL.L ${ }^{-1}$ & 0 & 6 & 6 & 13 \\
\hline
\end{tabular}

A firmeza da polpa dos frutos recém-colhidos foi de 78,7N. O 1-MCP foi eficiente em manter a firmeza da polpa durante o período de armazenamento apenas na concentração de 900 nL.L $\mathrm{L}^{-1}$ (Figura 6). A partir do $8^{\circ}$ dia de armazenamento, os frutos tratados com 100 nL.L. $\mathrm{L}^{-1}$ ou 300 nL.L $\mathrm{L}^{-1}$, apresentaram uma brusca perda da firmeza tornando-se moles rapidamente não diferindo dos frutos não tratados $(20,2 \mathrm{~N})$, enquanto que os frutos tratados com $900 \mathrm{~nL} . \mathrm{L}^{-1}$ apresentavam $43,2 \mathrm{~N}$ neste mesmo período. Com o decorrer do armazenamento, esses frutos foram perdendo a firmeza e no $16^{\circ}$ dia de armazenamento apresentavam 27,5N. A firmeza de polpa do fruto é determinada pela força de coesão entre as pectinas. Com a evolução do amadurecimento ocorre atuação de enzimas pectinolíticas, que transformam a pectina insolúvel em solúvel e promovem o amolecimento dos frutos. $\mathrm{O}$ amadurecimento dos frutos é um dos processos do amadurecimento mais sensíveis ao etileno (Lelièvre et al., 1997). A maior firmeza dos frutos tratados com 900 nL.L ${ }^{-1}$ de 1-MCP está provavelmente associada à redução da atividade das enzimas pectinolíticas, induzida pela menor ação do etileno e pela baixa temperatura de armazenamento.

O teor de acidez total titulável foi influenciado pelo 1-MCP, os frutos tratados com 1-MCP apresentaram maior teor de ácido cítrico do que os frutos não tratados independente da concentração aplicada (Figura 6). Os ácidos são uma mportante fonte de energia respiratória nas células (Ulrich, 1970). Por serem substrato da respiração, a concentração dos ácidos orgânicos diminui durante o amadurecimento em resposta a 
maior exigência metabólica (Wills et al., 1981). Provavelmente, o teor de ácido cítrico foi maior devido à retenção ao amadurecimento causada pelo 1-MCP associado a refrigeração.

A coloração da polpa, o teor de sólidos solúveis e o teor de vitamina C também não foram influenciados pelo 1-MCP (Figura 6). É possível que a ausência de efeitos do 1-MCP sobre as variáveis cor da polpa, teor de sólidos solúveis e vitamina $\mathrm{C}$ esteja ligada à presença de grande quantidade de receptores de etileno na polpa, apesar de se observar uma tendência de melhor manutenção dessas variáveis com o aumento da concentração de 1-MCP.

A perda de massa aumentou com o período de armazenamento, mas não foi influenciada pelo tratamento com 1-MCP (Figura 6). A perda de massa do fruto colhido é oriunda da respiração e transpiração (Hardenburg et al, 1986). Dada a capacidade do 1MCP em reduzir a respiração (Abdi et al., 1998; Golding et al., 1998) poderia-se esperar uma menor perda de massa nos frutos tratados. De fato, a respiração reduz a massa do fruto, mas numa proporção bem menor do que a transpiração, onde o 1-MCP parece não promover efeito.

Os frutos armazenados a $10^{\circ} \mathrm{C}$ apresentaram uma pequena variação na taxa respiratória no decorrer do armazenamento variando de 10 a $15 \mathrm{mgCO} 2 \cdot \mathrm{kg}^{-1} \cdot \mathrm{h}^{-1}$ (Figura 7). Provavelmente devido a baixa temperatura de armazenamento juntamente com o efeito do 1-MCP que reduz as reações metabólicas dos frutos. 

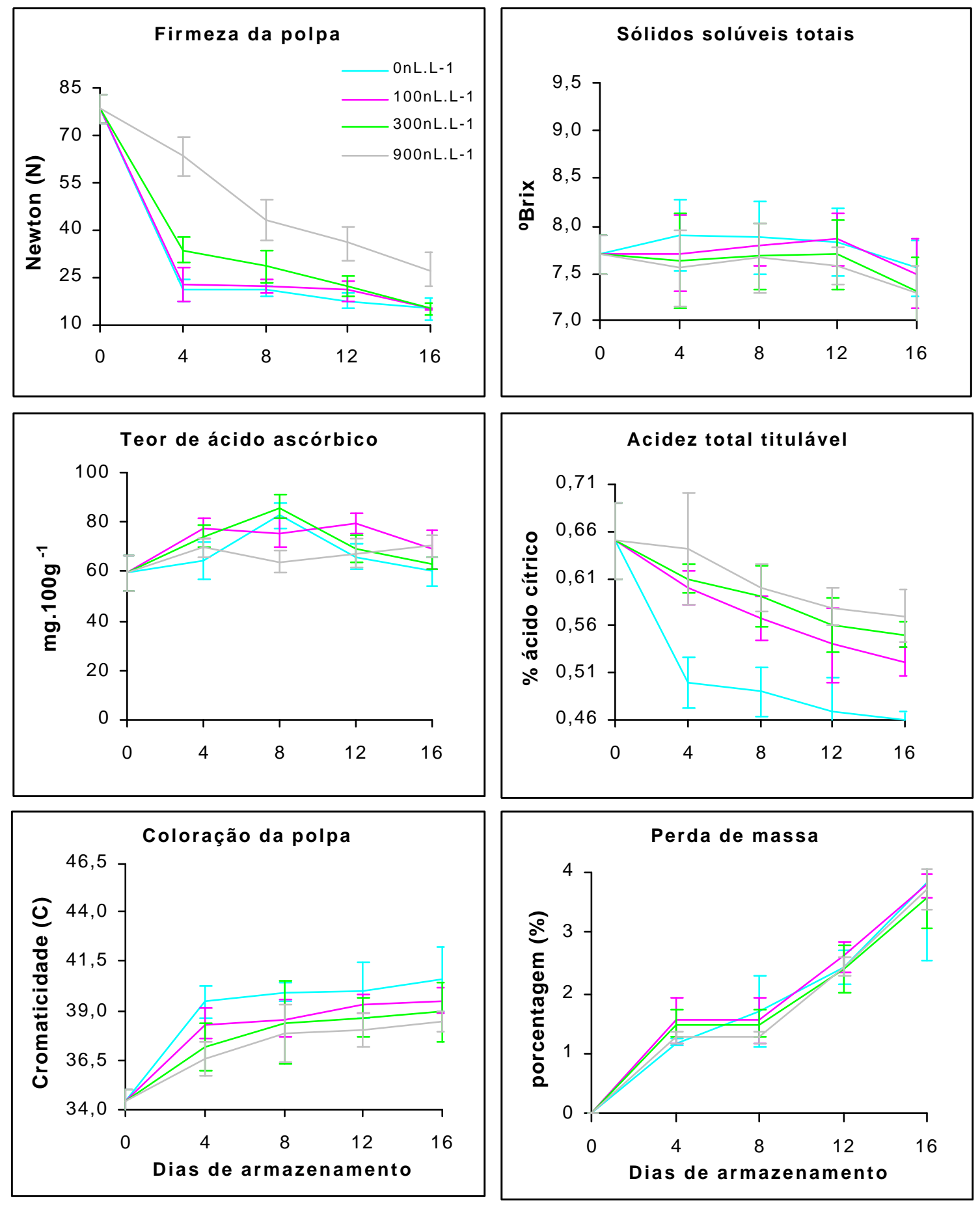

Figura 6 - Firmeza da polpa, sólidos solúveis totais, teor de ácido ascórbico, acidez total titulável, coloração da polpa e perda de massa de goiabas 'Pedro Sato' tratadas com 1-MCP durante $3 \mathrm{~h}$ e armazenadas a $10^{\circ} \mathrm{C}+2$ dias a $25^{\circ} \mathrm{C}$. 


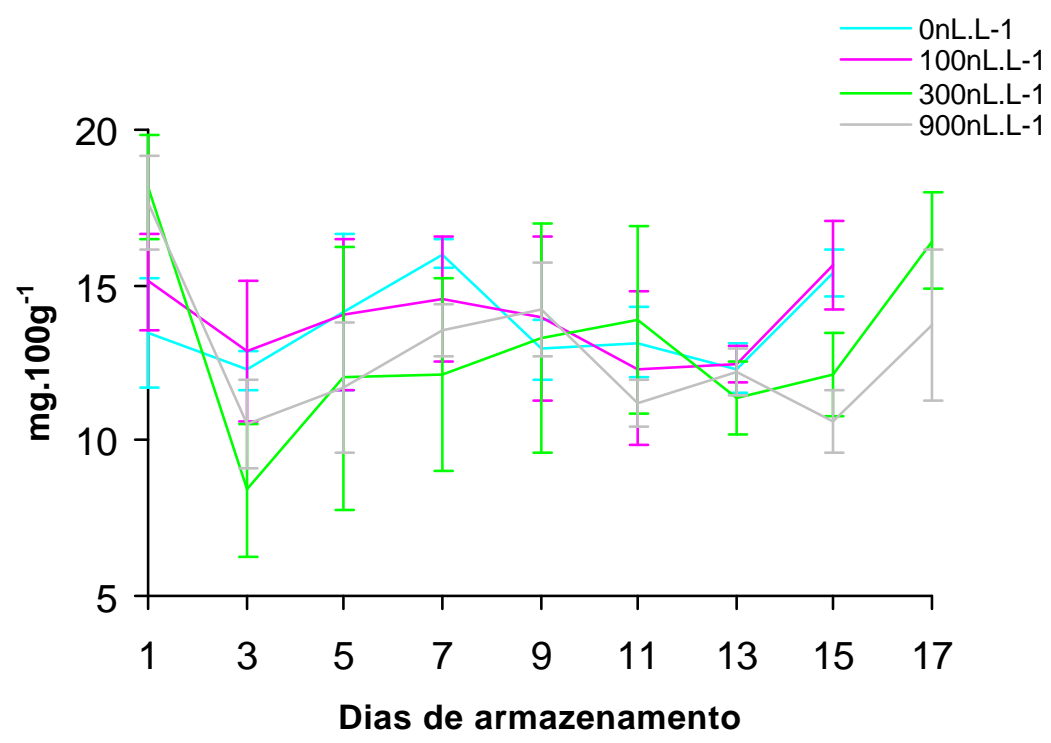

Figura 7 - Taxa respiratória de goiabas 'Pedro Sato' tratadas com 1-MCP durante 3 h e armazenadas a $10^{\circ} \mathrm{C}$.

Pelo presente trabalho, verificou-se que o 1-MCP foi eficaz em retardar o amadurecimento dos frutos armazenados tanto a $25^{\circ} \mathrm{C}$ quanto a $10^{\circ} \mathrm{C}$. A aplicação de 900 nL. $\mathrm{L}^{-1}$ de 1 -MCP durante 3 horas foi eficiente em retardar a coloração da casca e a firmeza dos frutos nas duas temperaturas de armazenamento, enquanto que a concentração de 300 nL.L ${ }^{-1}$ de 1-MCP apenas mostrou-se eficiente em retardar a coloração da casca quando os frutos foram armazenados a $10^{\circ} \mathrm{C}$, provavelmente devido a adição ao efeito da baixa temperatura sobre a taxa metabólica dos frutos. A concentração de $100 \mathrm{~nL} . \mathrm{L}^{-1}$ de 1-MCP, foi considerada baixa, pois não diferiu do tratamento controle nas duas temperaturas de armazenamento. $\mathrm{O}$ efeito do 1-MCP foi bastante significativo em diminuir a incidência das podridões nas duas temperaturas de armazenamento. Mostrando maior eficiência quando associado ao armazenamento refrigerado. No armazenamento a $25^{\circ} \mathrm{C}$ foi verificado menor teor de sólidos solúveis nos frutos tratados com 300 e 900 nL.L ${ }^{-1}$ de 1-MCP. No armazenamento a $25^{\circ} \mathrm{C}$, o teor de ácido cítrico foi maior nos frutos tratados com $900 \mathrm{~nL} . \mathrm{L}^{-1}$ de $1-\mathrm{MCP}$, enquanto que no armazenamento a $10^{\circ} \mathrm{C}$ não houve diferença entre os frutos tratados que obtiveram um maior teor que os 
frutos não tratados. Os frutos armazenados a $25^{\circ} \mathrm{C}$ e tratados com 900 nL. $\mathrm{L}^{-1}$ de $1-\mathrm{MCP}$ apresentaram menor intensidade da coloração da polpa. Para os frutos armazenados a $10^{\circ} \mathrm{C}$, não houve influência do $1-\mathrm{MCP}$ nas variáveis coloração da polpa e teor de sólidos solúveis totais. O teor de ácido ascórbico não foi influenciado pelo 1-MCP nas duas temperaturas de armazenamento. A taxa respiratória foi menor nos frutos tratados com 300 e 900 nL. $\mathrm{L}^{-1}$ de $1-\mathrm{MCP}$ durante o armazenamento a $25^{\circ} \mathrm{C}$. Para os frutos armazenados a $10^{\circ} \mathrm{C}$ a taxa respiratória manteve-se praticamente constante.

\subsection{Conclusões}

$\checkmark$ O 1-MCP foi eficiente em retardar o amadurecimento dos frutos em condição ambiente e sob refrigeração.

$\checkmark$ A concentração de 900 nL.L $\mathrm{L}^{-1}$ de 1-MCP foi considerada a mais eficiente em retardar o amadurecimento do fruto nas duas temperaturas de armazenamento.

$\checkmark$ Frutos tratados com 900 nL.L ${ }^{-1}$ de 1 -MCP durante 3 horas podem ser conservados por até 6 dias a $25^{\circ} \mathrm{C}$ e por até 16 dias a $10^{\circ} \mathrm{C}+2$ dias a $25^{\circ} \mathrm{C}$. 


\section{CONCLUSÕES GERAIS}

Do estudo de concentrações de 1-MCP e tempos de exposição para a conservação de goiabas 'Pedro Sato' armazenadas sob condição ambiente e sob refrigeração, obteve-se as seguintes conclusões:

a) com relação as concentrações de $0,60,120$ e 240 nL. $\mathrm{L}^{-1}$ de 1 -MCP durante 3, 6 e $12 \mathrm{~h}$ em ambiente refrigerado

$\checkmark$ O 1-MCP não foi eficiente em retardar o amadurecimento de goiabas 'Pedro Sato' armazenadas a $10^{\circ} \mathrm{C}$, nas concentrações e tempos de exposição estudados;

b) com relação as concentrações de $0,100,300$ e 900 nL.L ${ }^{-1}$ de 1-MCP durante 3, 6 e 12h em condição ambiente

$\checkmark$ O 1-MCP foi eficiente em retardar o amadurecimento de goiabas 'Pedro Sato' mantidas sob condição ambiente.

$\checkmark$ A eficiência do tratamento com 1-MCP depende da relação concentração $\mathrm{x}$ tempo de exposição. À medida que se aumenta a concentração, pode-se diminuir o tempo de exposição obtendo-se o mesmo efeito.

$\checkmark$ A concentração de 300 nL.L ${ }^{-1}$ de 1-MCP durante 6 e 12 h, e a concentração de 900 nL. $\mathrm{L}^{-1}$ durante 3 horas, permitiram a conservação de goiabas por 9 dias. 
$\checkmark$ A concentração de 900 nL.L $L^{-1}$ de 1-MCP durante 6 ou 12 horas, não é recomendada para goiaba por não permitir o posterior amadurecimento dos frutos.

c) com relação as concentrações de $0,100,300$ e $900 \mathrm{~nL} . \mathrm{L}^{-1}$ de 1 -MCP durante $3 \mathrm{~h}$ em condição ambiente e sob refrigeração

$\checkmark$ O 1-MCP foi eficiente em retardar o amadurecimento dos frutos em condição ambiente e sob refrigeração.

$\checkmark$ A concentração de 900 nL.L $\mathrm{L}^{-1}$ de 1-MCP foi considerada a mais eficiente em retardar o amadurecimento do fruto nas duas temperaturas de armazenamento.

$\checkmark$ Frutos tratados com 900 nL.L ${ }^{-1}$ de 1 -MCP durante 3 horas podem ser conservados por até 16 dias em ambiente refrigerado. 


\section{REFERÊNCIAS BIBLIOGRÁFICAS}

ABDI, N.; McGlassON, W. B.; HOLFORD, P. et. al. Responses of climateric and suppresed-climateric plums to treatment with propylene and 1-methlcyclopropene. Postharvest Biology and Technology, v. 14, p.29-39, 1998.

AHLAWAT, V.P.; YAMDAGNI, R.; JINDAL, D.C. Studies on the effect of postharvest treatments on storage behavior of guava (Psidium guajava L.) cv. Sardar (L.49). Haryana Agricultural University Journal of Research, v.10, n.2, p.244$247,1980$.

AKAMINE, E.K.; GOO, T. Respiration and ethylene production in fruits of species and cultivars of Psidium and species of Eugenia. Journal of the American Society for Horticultural Science, v.104, n.5, p.632-635, 1979.

ALI, Z.M.; LAZAN, H. Guava. In: MITRA, S.K. Postharvest of physiology and storage of tropical and subtropical fruits. Wallingford: $C A B$ internacional, 1997. cap.6, p.145-165.

BEAUDRY, R.; SCHWALLIER, P.; LENNINGTON, M. Apple maturity prediction: an extension tool to and fruit storage decisions. HortTechnology, v.3, n.2, p.233-239, 1993.

BIALE, J. B.; BARCUS, D. E. Respiratory patterns in tropical fruits of the amazon Basin. Tropical Science, v.12, p.93-104, 1970. 
BLANKENSHIP, S.M.; SISLER, E.C. 2,5-norbornadiene retards apple softening. HortScience, v.24, p.313-314, 1989.

BLANKENSHIP, S.M.; SISLER, E.C. Response of apples to diazocyclopentadiene inhibition of ethylene binding. Postharvest Biology and Technology, v.3, p.95-101, 1993.

BLEINROTH, E.W., SIGRIST, J.M.M., ARDITO, E.F.G. et al. Tecnologia de póscolheita de frutas tropicais. Campinas: ITAL, 1992. 203p. (Manual Técnico, 9).

BOTREL, N.; FREIRE, M.J.; VASCONCELOS, R.M. et al. Inibição do amadurecimento da banana 'Prata-Anã' com a aplicação do 1-metilciclopropeno. Revista Brasileira de Fruticultura, v.24, n.1, p.53-56, 2002.

BROWN, B.I.; WILLS, R.B.H. Post-harvest changes in guava fruit of different maturing. Scientia Horticulturae, v.19, n. 3/p.237 -243, 1983.

BRUISMA, J. Hormonal regulation of senescence, ageing, fading and ripening. In: LIEBERMANN, M. Postharvest physiology and crop preservation. Mariland : Nato Advanced Study Institutes Series, 1981. p. 141-163. (Série A: Life Science, 46).

BURG, S.P. The physiology of ethylene formation. Annual Review in Plant Physiology, v.13, p.265-302, 1962.

BURG, S.P.; BURG, E.A. Molecular requeriments for the biological activity of ethylene. Plant Physiology, v.42, p.144-152, 1967.

CARVAlHO, C.R.L.; MANTOVANI, D.M.B.; CARVALHO, P.R.N. et al. Análises químicas de alimentos. Campinas: ITAL, 1990. 121p. (Manual Técnico). 
CARVALHO,V.D. Qualidade e conservação pós-colheita de goiabas. Informe Agropecuário, v.17, n.179, p.48-54, 1994.

CASTRO, J.V. de; SIGRIST, J.M.M. Matéria-prima. In: INSTITUTO DE TECNOLOGIA DE ALIMENTOS. Goiaba: cultura, matéria-prima, processamento e aspectos econômicos. 2.ed. Campinas, 1991.p.121-139. (ITAL. Série Frutas Tropicais, 6).

CHITARRA, M.I.F.; CHITARRA, A.B. Pós-colheita de frutas e hortaliças: fisiologia e manuseio. Lavras: ESAL, FAEPE, 1990. 320p.

CHOUDHURY, M.M. (Ed.) Goiaba: pós-colheita. Petrolina: Embrapa Semi-árido, 2001. 45p.

COMBRINK, J.C.; KOCK, S.L.; VAN EEDEN, C. Effect of post-harvest treatment and packaging on the keeping quality of fresh guava fruit. Acta Horticulturae, n.275, p.639-645, 1990.

DEELL, R.J.; MURR, D.P.; PORTEOUS, M.D. et al. Influence of temperature and duration of 1-methylcyclopropene (1-MCP) treatment on apple quality. Postharvest Biology and Technology, v. 24, n.3, p.349-353, 2002.

DUPILLE, E.; SISLER, E.C. Effects of ethylene receptor antagonist on plant material. In: AIT-OUBAHOU, A.; EL-OTMANI, M. (E4d.) Postharvest, pathology and technologies for horticultural commodities: recents advances. Agadir: Institute Agronomique et Veterimaire Hassan II., 1995. p.294-301.

DURIGAN, J.F. Colheita, conservação e embalagens. In: SIMPÓSIO BRASILEIRO SOBRE A CULTURAS DA GOIABEIRA, 1., Jaboticabal, 1995. Anais. Jaboticabal: FUNEP, 1997. p.149-158. 
FAN, X.; MATTHEIS, J.P. Yellowing of broccoli in storage is reduced by 1methylcyclopropene. HortScience, v. 35, n.5, p.885-887, 2000.

FAN, X.; ARGENTA, L.; MATTHEIS, J.P. Inhibition of ethylene action by 1methylcyclopropene prolongs storage life of apricots. Postharvest Biology and Technology, v. 20, p.135-142, 2000.

FAN, X.; ARGENTA, L.; MATTHEIS, J.P. Interactive effects of 1-MCP and temperature on 'Elberta' peach quality. HortScience, v.37, n.1, p. 134-138, 2002.

FAN, X.; BLANKENSHIP, S.M.; MATTHEIS, J.P. 1-methylcyclopropene inhibits apple ripening. Journal of the American Society for Horticultural Science, v.124, n.6, p.690-695, 1999.

FENG, X.; APELBAUM, A.; SISLER, E.C. et al. Control of ethylene responses in avocado fruit with 1-methylcyclopropene. Postharvest Biology and Technology, v.20, p. 143-150, 2000.

FNP CONSULTORIA \& COMÉRCIO. Agrianual 2000: anuário estatístico da agricultura brasileira. São Paulo, 2000. p.360-365.

FNP CONSULTORIA \& COMÉRCIO. Agrianual 2001: anuário estatístico da agricultura brasileira. São Paulo, 2001. p.364-368.

GASPAR, J.W.; COUTO, F.A.A.; SALOMÃO, L.C. et al. Effect of low temperature and plastic films on post-harvest life of guava (Psidium guajava L.). Acta Horticulturae, n.452, p.107-114, 1997. 
GOLDING, J.B.; SHEARER, D.; WYLLIE, S. et al. Application of 1-MCP and propylene to identify ethylene-dependent ripening process in mature banana fruit. Postharvest Biology and Technology, v. 14, p.87-98, 1998.

GONG, Y.; JIAN, M.S. Inibitory effect of diazocyclopentadiene on the development of superficial scald in 'Granny Smith' apples. Plant Growth Regulation, v.26, p.117121, 1998.

GONGATTI NETO, A; GARCIA, A.E.; ARDITO, E.F.G. et al. Goiaba para exportação: procedimentos de colheita e pós-colheita. Brasília: EMBRAPA, SPI, 1996. 35p. (FRUPEX, 20).

GONZAGA NETO, L.; CRISTO, A.S.; CHOUDHURY, M.M. Conservação póscolheita de goiabeira, variedade paluma. Pesquisa Agropecuária Brasileira, v.34, n.1, p.1-6, 1999.

GRAN, C.D., BEAUDRY, R.M. Modified atmosphere packaging determination of lower oxygen limits for apple fruit using respiratory quotient and ethanol accumulation. In: INTERNATIONAL CONTROLLED ATMOSPHERE RES.CONFERENCE, 6., Ithaca, 1996. Proceedings. Ithaca: Cornell University, 1993. v.1, p.54-62.

HANDERBURG, R.E.; WATADA, A.E.; WANG, C.Y. The commercial storage of fruits, vegetables, and florist, and nursery stocks. Washintong: USDA, 1986. 130p. (USDA. Agriculture Handbook,66)

HARRIS, D.R.; SEBERRY, J.A.; WILLS, R.B.H. et al. Effect of fruit maturity on efficiency of 1-methylcyclopropene to delay the ripening of bananas. Postharvest Biology and Technology, v.20, p. 303-308, 2000. 
INABA, A. Recent studies on postharvest physiology and technology of horticultural crops in Japan. Postharvest News and Information, v.4, n.4, p.101N-104N, 1993.

JACOMINO, A.P. Conservação de goiabas 'Kumagai' em diferentes temperaturas e materiais de embalagem. Piracicaba, 1999. 90p. Tese (Doutorado) - Escola Superior de Agricultura “Luiz de Queiroz”, Universidade de São Paulo.

JACOMINO, A.P. Armazenamento de goiabas 'Kumagai' sob diferentes temperaturas de refrigeração. Brazilian Journal of Food Technology, v.3, p.165-169, 2000.

JACOMINO, A.P. et al. Amadurecimento e senescência de mamão com 1metilciclopropeno. Scientia Agricola, v.59, n.2. p.303-308, 2002.

JEFFRIES, P.J.; DODD, J.C.; JEGER, M.J. et al. The biology and control of Colletotrichum species on tropical fruit crops. Plant Pathology, v.39, p.343-366, 1990.

JEONG, J.; HUBER, D.J.; SARGENT, S.A. Influence of 1-methylcyclopropene (1MCP) on ripening and cell-wall matrix polysaccharides of avocado (Persea americana) fruit. Postharvest Biology and Technology, v.25, n. 3, p. 241-256, 2002.

JIANG, Y.; JOYCE, D.C.; MACNISH, A.J. Extension of the shelf life of banana fruit by 1-methylcyclopropene in combination with polyethylene bags. Postharvest Biology and Technology, v.16, p.187-193, 1999a.

JIANG, Y.; JOYCE, D.C.; MACNISH, A.J. Responses of banana fruit to treatment with 1-methylcyclopropene. Plant Growth Regulation, v.28, p.77-82, 1999 b. 
KADER, A.A. Postharvest technology of horticultural crops. Oakland: University of California, 1992. 269p.

KADER, A.A. Postharvest technology of horticultural crops. Oakland:University of California, 1994. 296p.

KADER, A.A. Biochemical and physiological basis for effects of controlled and modified atmospheres on fruits and vegetables. Food Technology, v.40, n.5, p.99104. 1986.

KADER, A.A.; ZAGORY, D.; KERBEL, E.L. Modified atmosphere packaging of fruits and vegetables. Critical Reviews in Food Science and Nutrition, v.28, n.1, p.1-30, 1989.

KAYS, S.J. Postharvest physiology of perishable plant products. New York: AVI Publ., 1991. 532p.

KLUGE, R.A.; JACOMINO, A.P.; CASTRO, P.R.C. Controle do amadurecimento e senescência de goiaba vermelha tratada com ethylbloc (1-MCP). In: CONGRESSO BRASILEIRO DE FRUTICULTURA, 16., Fortaleza, 2000. Resumos. Fortaleza: EMBRAPA, 2000. p.292.

KLUGE, R.A; NACHTIGAL, J.C.; FACHINELLO, J.C. et al. Fisiologia e manejo póscolheita de frutas de clima temperado. 2.ed. Piracicaba: Livraria e Editora Rural, 2002. 214p.

KU, V.V.V.; WILLS, R.B.H. Effect of 1-methylcyclopropene on the storage life of broccoli. Postharvest Biology and Technology, v.17, p.127-132, 1999. 
KU, V.V.V.; WILLS, R.B.H.; BEN-YEHOSHUA, S. 1-Methylcyclopropene can differentially affect the postharvest life of strawberries exposed to ethylene. HortScience, v.34, n.1, p.119-120, 1999.

LELIÈVRE, J.M.; LATCHÉ, A.; JONES, B. et al. Ethylene and fruit ripening. Physiologia Plantarum, v.101, p.727-739, 1997.

LIMA, M.A.; DURIGAN, J.F.; TOSTES, D.R.D. Avaliação do comportamento respiratório de goiabas 'Pedro Sato' e a influência de diferentes embalagens na sua conservação sob refrigeração. In: CONGRESSO BRASILEIRO DE CI ECNIA E TECNOLOGIA DE ALIMENTOS, 16., Rio de Janeiro, 1998. Anais. Rio de Janeiro: SBCTA, p. 1980-1983, v.3. 1998.

MANICA, I.; ICUMA.I.M.; JUNQUEIRA, N.T.V. et al. Fruticultura tropical 6. Goiaba. Porto Alegre: Cinco Continentes, 2000. 374p.

McGUIRE, R.G. Reporting of objective color measurements. HortScience, v.17, n.12, p.1254-1255, 1992.

McGUIRE, R.G. Market quality of guavas after hot-water quarentine treatment and application of carnauba wax coating. HortScience, v.32, n.2, p.271-274, 1997.

MIR, N.A.; CURELL, E.; KHAN, N. et al. Harvest maturity, storage temperature and 1MCP aplication frequency alter firmness retention and chlorophyll fluorescence of 'Redchief Delicious' apples. Journal of the American Society for Horticultural Science, v.126, p.618-624, 2001. 
NAKATSUKA, A.; SHIOMI,S.; KUBO, Y. et al. Expression and internal feedback regulation of ACC syntethase and ACC oxidase genes in ripening tomato fruit. Plant Cell Physiology, v.38, p.1130-1110, 1997.

OJEDA, R.M. Utilização de ceras, fungicidas e sanitizantes na conservação de goiabas ‘ Pedro Sato’ sob condição ambiente. Piracicaba, 2001. 57p. Dissertação (Mestrado) Escola Superior de Agricultura “Luiz de Queiroz”, Universidade de São Paulo.

PANTASTICO, E.B.; CHATTOPADHYAY, T.K.; SUBRAMANYAM, H. Storage and commercial storage operations. In: PANTASTICO, E.B. (Ed.) Postharvest physiology, handling and utilization of tropical and subtropical fruits and vegetables. Westport: AVI, 1975. p. 314-338.

PEREIRA, F.M. Cultura da goiabeira. Jaboticabal : FUNEP, 1995. 47p.

PORAT, R.; HALEVY, A.H.; SEREK, M. et al. An increase in ethylene sensitivity following pollination is the initial event triggering in increase in ethylene production and enhanced senescence of Phalenopsis orchid flowers. Physiologia Plantarum, v.88, p.243-250, 1995.

RATHORE, D.S. Effect of season on the growth and chemical composition of guava (Psidium guajava L.) fruits. Journal of Horticultural Science, v.51, n.1, p.41-47, 1976.

REYES, M.U.; PAULL, R.E. Effect of storage temperature and ethylene treatment on guava (Psidium guajava L.) fruit ripening. Postharvest Biology and Technology, v.6, p.37-365, 1995. 
RUPASINGUE, H.P.V.; MURR, DP.; PALIYATH, G. et al. Inhibitory effect of 1-MCP on ripening and superficial scald development in 'McIntosh' and 'Delicious' apples. Journal of Horticultural Science \& Biotechnology, v.75, n.3, p.271-276, 2000.

SAHA, A.K. Effect of post harvest treatment with growth regulators on the ripening and chemical composition of guava (Psidium guajava L.) fruits. Indian Journal Horticultural, v.28, n.1, p.11-15, 1971.

SALUNKHE, D.K.; DESAI, B.B. Postharvest biotechnology of fruits. Boca Raton: CRC Press, v.2, 1984. 147p.

SEREK, M.; REID, M.S. Anti-ethylene treatments for potted flowering plants - relative efficacy of inhibitors of ethylene action and biosyntesis. HortScience, v.28, p. 1180$1181,1993$.

SEREK, M.; SISLER, E.C.; REID, M.S. A volatile ethylene inhibitor improves the postharvest life of potted roses. Journal of the American Society for Horticultural Science, v.119, p.572-577, 1994.

SEREK, M.; SISLER, E.C.; REID, M.S. 1-methylcyclopropene, a novel gaseous inhibitor of ethylene action, improves the life of fruit, cut flowers and potted plants. Acta Horticulturae, n.394, p.337-345, 1995.

SING, B.P; SING, H.K.; CHAUHAN, K.S. Effect of post-harvest calcium treatments on the storage life of guava fruits. Indian Journal of Agricultural Science, v.51, n.1, p.44-47, 1981.

SISLER, E.C.; SEREK, M. Inhibitors of ethylene responses in plants at the receptors level: recent developments. Physiologia Plantarum, v.100, p.577-582, 1997. 
SISLER, E.C.; SEREK, M.; DUPILLE, E. Comparison of cyclopropene, 1methylcyclopropene, and 3,3-dimethylcyclopropene as ethylene antagonists in plants. Plant Growth Regulation, v.18, p. 169-174, 1996.

SRIVASTAVA, H.C.; NARASIMHAN, P. Physiological studies during the growth and development of different varieties of guavas (Psidium guajava L.). Journal of Horticultural Science, v.48, p.97-104, 1967.

TUCKER, G.A. Introduction. In: SEYMOR, G.B.; TAYLOR, J.E.; TUCKER, G.A. Biochemistry of fruit ripening. London: Champmal \& Hall. 1993, cap.1, p.2-51.

ULRICH, R. Organic acids. In: HULNE, A.C. Biochemistry of fruits and their products. London: Academic Press, 1970, v.1, p.89-118.

VASQUEZ-OCHOA, R.J.; COLINAS-LEON, M.T. Changes in guavas of three maturity stages in response to temperature and relative humidity. HortScience, v.25, n.1, p.86-87, 1990.

WATKINS, C.B.; NOCK, J.F.; WHITAKER, B.D. Responses of early, mid and late season apple cultivars to postharvest application of 1-methylcyclopropene (1-MCP) under air and controlled atmosphere storage conditions. Postharvest Biology and Technology, v.19, p.17-32, 2000.

WILLS, R.H.H.; LEE, T.H.; GRAHAM, W.B. et al. Postharvest: an introduction to the physiology and handling of fruit and vegetables. Kensington: New South Wales University Press, 1981. 161p.

YAHIA, E.M. Modified and controlled atmospheres for tropical fruits. Horticultural Reviews. v.22, p.123-149, 1998. 
YAMASHITA, F.; BENASSI, M.T. Influência de fiferentes embalagens de atmosfera modificada sobre a aceitação de goiabas brancas de mesa (Psidium guajava L., var. Kumagai) mantidas sob refrigeração. Alimentos e Nutrição, v.9, p.9-16, 1998.

YUSOF, S.; HASHIM, H. Hot water versus vapour heat treatment and their effects on guava (Psidium guajava L.) fruits. Acta Horticulturae, v.292, p.217-221, 1992.

XISTO, A.L.R.P. Conservação pós-colheita de goiaba 'Pedro Sato' com aplicação de cloreto de cálcio em condições ambiente. Lavras, 2002. 47p. Dissertação (Mestrado). - Universidade Federal de Lavras.

ZAMBÃO, J.C.; BELLINTANI NETO, A.M. A cultura da goiaba. Campinas: CATI, 1998. 23p. (Boletim Técnico, 236). 